\title{
New petrified calamitaleans from the Permian of the Parnaíba Basin, central-north Brazil, part II, and phytogeographic implications for late Paleozoic floras
}

\author{
Rodrigo Neregato ${ }^{\mathrm{a}, *}$, Ronny Rößler ${ }^{\mathrm{b}, \mathrm{c}}$, Roberto Iannuzzi ${ }^{\mathrm{d}}$, Robert Noll ${ }^{\mathrm{e}}$, Rosemarie Rohn ${ }^{\mathrm{f}}$ \\ a UNESP - Rio Claro, Post Graduation Program in Regional Geology, Institute of Geosciences and Exact Science, Postal Code: 13506-900 Rio Claro, São Paulo, Brazil \\ ${ }^{\mathrm{b}}$ Museum für Naturkunde, Moritzstraße 20, D-09111 Chemnitz, Germany. \\ c TU Bergakademie Freiberg, Geological Institute, Bernhard-von Cotta Straße 2, D-09596 Freiberg, Germany \\ d Department of Paleontology and Stratigraphy, Institute of Geosciences, Universidade Federal do Rio Grande do Sul, Caixa Postal 15.001, Postal Code: 91.509-900, Porto Alegre, Brazil \\ e In den Birkengärten 30, D-67311 Tiefenthal, Germany \\ ${ }^{\mathrm{f}}$ UNESP - Rio Claro, Department of Applied Geology, Institute of Geosciences and Exact Science, Caixa Postal 178, Postal Code: 13506-900, Rio Claro, São Paulo, Brazil
}

\section{A R T I C L E I N F O}

\section{Article history:}

Received 15 December 2015

Received in revised form 9 November 2016

Accepted 9 November 2016

Available online 13 November 2016

\section{Keywords:}

Sphenophyte anatomy

Growth architecture

Plant interactions

Permian phytogeography

\begin{abstract}
A B S T R A C T
Continuing palaeofloristic studies in the Northern Tocantins Fossil Forest, we describe two new calamitalean species from the Permian of the Parnaíba Basin (central-north Brazil). The fossils comprise axes of various sizes, preserved anatomically as siliceous petrifactions, and found in highly mature sandy fluvial deposits of the Motuca Formation. Based on anatomical and morphological characteristics, Arthropitys tocantinensis sp. nov. and Arthropitys barthelii sp. nov. are described. They share a small central pith cavity (extremely reduced in the latter), scalariform tracheid pitting, and prominent pitting of the ray parenchyma. However, they differ markedly in their branching system: the former having 3-12 branches per node either with or lacking secondary growth, the latter showing 2-17 branches without any secondary growth. However, in A. tocantinensis sp. nov., the presence of large woody branches supports a more complex architecture with at least three successive orders of branches. The extensive secondary tissue in both species is homogeneous; clear segmentation is only visible in the proximal wood of A. tocantinensis sp. nov., but completely absent in A. barthelii sp. nov.

The growth architecture of these upright growing, self-supporting trunks are reconstructed based on sizable transverse and longitudinal preparations. Our results confirm that thick woody calamitaleans were elements of disturbed riparian vegetation and much more diverse in terms of anatomy and branching patterns than previously thought. They were well adapted to seasonally dry conditions and formed major plant constituents of Permian low-latitude Southern Hemisphere communities. Additionally, we report the first evidence of colonisation on arborescent calamitaleans by herbaceous sphenophyte axes from the Permian. One of the Arthropitys stems hosts at least 30 Sphenophyllum shoots of various ontogenetic stages, growing inside the destroyed pith, which was previously excavated by arthropod boring.

Based on the distribution of key genera within late Paleozoic floras of Euramerica, Gondwana and Cathaysia floral realms cluster analysis and Jaccard Coefficient highlight the distribution of a "Mid-North Brazilian" phytogeographic Region during the early Permian.
\end{abstract}

(C) 2016 Elsevier B.V. All rights reserved.

\section{Introduction}

Petrified plants from the Permian of Brazil have been mentioned in the literature for almost one and a half centuries (Brongniart, 1872). However, only the most common psaroniaceous tree ferns, such as the nearly cosmopolitan Psaronius or the Southern Hemisphere Tietea

\footnotetext{
* Corresponding author.

E-mail addresses: rodrigoneregato@hotmail.com (R. Neregato), roessler@naturkunde-chemnitz.de (R. Rößler), roberto.iannuzzi@ufrgs.br (R. lannuzzi), r.h.noll@t-online.de (R. Noll), rohn@rc.unesp.br (R. Rohn).
}

have been studied in detail (Solms-Laubach, 1913; Herbst, 1985, 1992, 1999). Despite the long history of paleobotanical research in Brazil, the first record of three-dimensionally preserved calamitaleans appeared only 30 years ago. Coimbra and Mussa (1984) identified Arthropitys, the most common petrified sphenophyte genus, among several new finds from the Parnaíba Basin of north-central Brazil and erected Arthropitys cacundensis Mussa and Coimbra, 1984. Although the small stem or branch fragment found in the Cacunda River, situated between Araguaína (TO) and Carolina (MA), left no doubt regarding the identification at generic level, its size and preservation were hardly adequate to be discussed at specific level, especially in comparison to more 
comprehensively characterised species, such as Arthropitys communis (Binney) Renault, 1896, A. deltoides Cichan and Taylor, 1983 or more recently the type species of the genus, Arthropitys bistriata (Cotta) Goeppert emend. Rößler et al., 2012.

During the last decade, exposures of the extensive fluvial depositional complex of the Motuca Formation revealed not only new aspects of late Paleozoic vegetational diversity and distribution, but also insights into intra-Permian environmental and climatic development. The border region of southern Maranhão State and northern Tocantins State has yielded numerous large and well-preserved plant fossils, which have expanded our knowledge of low-latitude Gondwanan palaeofloras (Rößler and Noll, 2002; Rößler and Galtier, 2002a,b, 2003; Rößler, 2006). Recently, several detailed studies have shed light on taphonomic or palaeoenvironmental aspects of the host strata (Capretz and Rohn, 2013; Tavares et al., 2014) and initiated systematic investigations of additional plant groups, such as gymnosperms (Kurzawe et al., 2013a,b). Still under open nomenclature, Rößler and Noll (2002) and Neregato (2012) described several new calamitalean forms based on numerous specimens that reveal not only information on anatomy and branching characteristics of their aerial parts, but also initial rooting structures. During field work in 2006, two large woody calamite trunks were excavated revealing clear evidence of basal stems with attached roots. Providing new information on calamitalean root systems in general, Rößler (2014) and Rößler et al. (2014) compared them with similar in-situ rooting forms from the Chemnitz Fossil Lagerstätte in eastern Germany and characterised some of the common Permian species as free-stemmed woody trees anchored in the former soil substrate by numerous secondary roots arising from multiple nodes of the enlarged trunk base and branching several times on their oblique downward course. Neregato et al. (2015) initiated systematic description of new calamitalean species from the Panaíba Basin and introduced Arthropitys isoramis and Arthropitys iannuzzii.

That fieldwork and the newly discovered fossil sites in the northern part of Tocantins State emphasized the importance of this region as a Permian fossil Lagerstätte and inspired the Brazilian Government to create the Tocantins Fossil Trees Natural Monument (Dias-Brito et al., 2007). However, although the Parnaíba Basin received special attention during recent years, and several taxa have been described recently, the region's palaeophytogeographic setting remains poorly investigated. Based on the presence of Psaronius and the absence of Glossopteris, Dolianiti (1972) suggested an affinity with Europe and North America. Based on the presence of Arthropitys, Amyelon, and Artisia, Coimbra and Mussa (1984) and Mussa and Coimbra (1987) suggested an affiliation to the Euramerican Province but, on the other hand, the presence of Taxopitys suggests an affiliation to Gondwana. Rößler and Galtier (2002a) described Grammatopteris freitasii from this basin, a genus otherwise restricted to France and Germany, but with close relations to the filicalean Rastropteris from Cathaysia (Galtier et al., 2001). More recently, Kurzawe et al. (2013b) identified Damudoxylon, Taeniopitys and Kaokoxylon in the Parnaíba Basin - all genera typically from Gondwana.

In this second contribution we continue describing arboreal sphenophytes introducing two additional species, Arthropitys tocantinensis sp. nov. and Arthropitys barthelii sp. nov., and we initiate a discussion concerning the palaeophytogeographic position of the Parnaíba Basin during the Cisuralian.

\section{Material and methods}

The specimens were found in the southern part of the Parnaíba Basin, between Filadélfia and Araguaína cities, State of Tocantins, central-north Brazil (Fig. 1). In order to investigate the morphological and internal structure of the petrified specimens, we used a sand blaster to remove the psammitic sediment and expose the surface. The specimens were subsequently cut with a trimming saw to reveal both transverse and longitudinal (radial and tangential) sections. These surfaces were ground and polished applying standard procedures. Cellular structures were examined and photographed under reflected light using a Nikon DS-5M-L1 digital camera attached to Nikon Eclipse ME 600 and Nikon SMZ 1500 microscopes. Morphological overviews were photographed with a Nikon D 200 camera; larger polished surfaces were digitalised using an Epson Perfection V330 scanner. Composite images were created using Corel Draw version X6 and corrected only for contrast and colour. The specimens are stored in the Museum für Naturkunde, Chemnitz, Germany, labelled as K 4965, K 5266, K 5399, K 5455, K 5456, K 5787, K 5500, K 4874, and K 6040. The paleophytogeographical analysis and the Jaccard Coefficient were ascertained using PAST (Hammer et al., 2001).

\section{Systematic paleontology}

Class Sphenopsida

Order Calamitales

Family Calamitaceae

Genus: Arthropitys Goeppert, 1864-1865

Type-species: Arthropitys bistriata (Cotta) Goeppert emend. Rößler et al., 2012

Arthropitys tocantinensis sp. nov. Neregato, Rößler et Noll

Holotype: K 4965.

Paratype: K 5266.

Additional material: K 5399, K 5455, K 5456.

Type locality: Northern Tocantins Petrified Forest, Tocantins State, Parnaíba Basin, central-north Brazil.

Type stratum: Motuca Formation, Permian.

Etymology: The specific name refers to the State from which this species was identified Tocantins, central-north Brazil.

Diagnosis: Branching system composed of variable number (mostly 3-12) of branches occurring at every node, superposed or alternating along the stem, with and without secondary growth. Segmentation of fascicular wedges and interfascicular rays only visible within the proximal wood. Secondary xylem tracheids with exclusively scalariform pitting. Ray parenchyma with pitted horizontal walls.

Description

General features and taphonomy - The holotype, K 4965, an erosional remnant of a petrified trunk represents the basal portion of a branched woody stem (Plate I, 1). The specimen was found embedded in well-rounded, well-sorted, and medium-grained fluvial quartz sandstone (grain size: 293 [140-670] $\mu \mathrm{m}$ ), not always easily removable from the stem; in some cases the adhering sandstone is also strongly silicified up to $40 \mathrm{~mm}$ from the axis. The stem surface is partially eroded depending on the extent of silicification, therefore no extraxylary tissues are preserved. The stem base is enlarged, probably forming a woody root stock with obliquely downwardly oriented woody projections and scars (Plate I, 1, lower part). However, the eroded stem surface prohibits to recognise further morphological detail. At the top of the specimen, woody branches indicate a three-dimensional branching architecture. The two woody branches, probably originating from the bifurcation of the stem, measure $26 \times 44 \mathrm{~mm}$ and $63 \times 90 \mathrm{~mm}$ in diameter, with the longest including an angle with the uppermost stem of $55^{\circ}$. The stem portion is $1850 \mathrm{~mm}$ long with its largest width at the base of $130 \times 213 \mathrm{~mm}$, girth of $554 \mathrm{~mm}$; the pith cavity at the base measures $2 \times 9 \mathrm{~mm}$. Above $260 \mathrm{~mm}$ the base, stem diameter measures $90 \times 119 \mathrm{~mm}$, pith cavity is $7.5 \times 13.5 \mathrm{~mm}$ wide and girth is $448 \mathrm{~mm}$ (Plate I, 4). Beneath $350 \mathrm{~mm}$ of the upper end, the stem diameter measures $95 \times 105 \mathrm{~mm}$ (Plate I, 3); At the top, the stem diameter measures $52 \times 62 \mathrm{~mm}$, pith cavity is $9 \times 20 \mathrm{~mm}$ and girth is $180 \mathrm{~mm}$ (Plate I, 2). Largest pith cavity diameter of $19 \times 25.5 \mathrm{~mm}$ occurs $530 \mathrm{~mm}$ from the upper end of the stem portion. Nodes are barely visible on the stem's surface; on one radial section (Plate II, 1) internode length is $63 \mathrm{~mm}$.

The paratype, $\mathrm{K} 5266$, represents a branched stem portion from the upper tree (crown position) likewise partly embedded in mediumgrained quartz sandstone. The specimen is $1170 \mathrm{~mm}$ long and bears numerous closely spaced nodes with internode lengths at the lower end of 


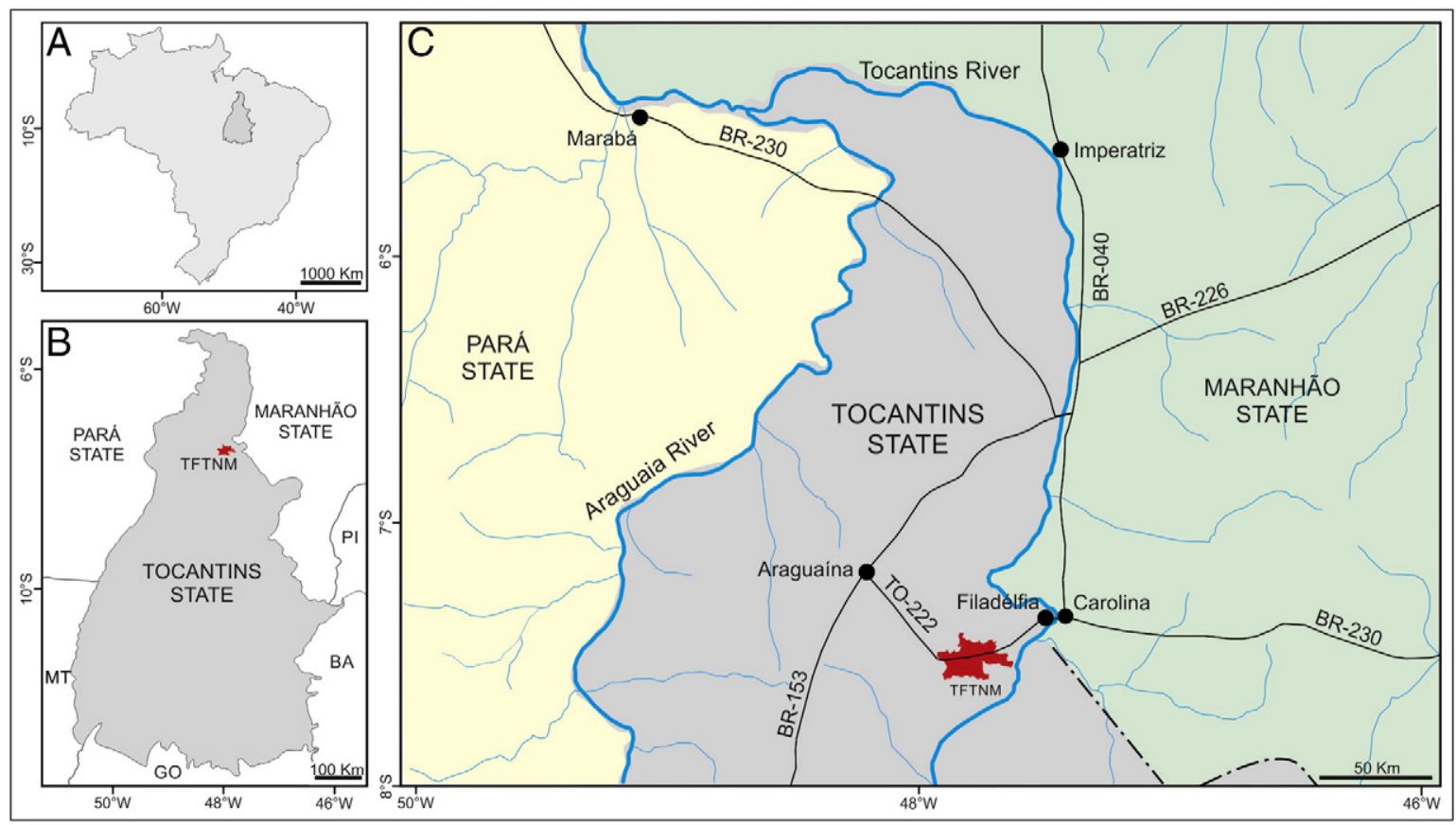

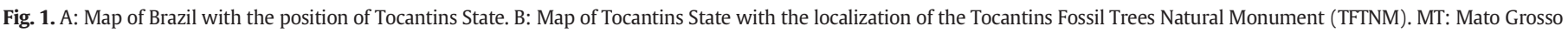

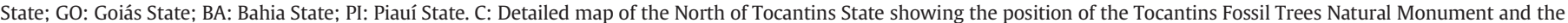
most important municipalities around it.

12-20 mm, and at the upper end of 9-12 mm (Plate III, 1-2; Plate IV, 2 3 ). The stem diameter at the lower end is $87 \mathrm{~mm}$, and at the upper end $65 \mathrm{~mm}$. Pith cavity diameter is approximately $15 \mathrm{~mm}$ at the lower end diminishing to $8 \mathrm{~mm}$ at the upper end.

$\mathrm{K} 5456$ (Plate V, 1) represents a stem/branch portion, $276 \mathrm{~mm}$ long. The diameter at the lower end is $35 \times 38 \mathrm{~mm}$, pith cavity spans $13 \times 14 \mathrm{~mm}$ surrounded by 62 vascular strands (Plate $V, 5,8$ ), presenting asymmetric secondary body (Plate $V, 4$ ). At the upper end, the stem diameter is $36 \times 44 \mathrm{~mm}$, pith cavity spans $12 \times 13 \mathrm{~mm}$ and is surrounded by 62 vascular strands (Plate V, 2). Eleven nodes are visible (counted from three portions belonging to the specimen), internode distances are 27 (15-36) mm (Plate V, 1); several nodes show branch traces (up to 10 visible). Additionally, two large branch traces, $11 \times 13 \mathrm{~mm}$ and $24 \times 26 \mathrm{~mm}$ in diameter and showing extended secondary growth, are visible at the stem surface (Plate $\mathrm{V}, 1$ ).

K 5455 (Plate V, 6, 7) is an erosional remnant of a stem, $198 \mathrm{~mm}$ long, $69 \times 85 \mathrm{~mm}$ in diameter. The pith cavity is asymmetric, $15 \times 19 \mathrm{~mm}$ in diameter and surrounded by approximately 80 vascular strands. Three nodes are visible on the surface bearing several branch traces, which in some cases became overgrown during secondary growth of the stem. A few of the side branches enlarged during secondary growth to form woody branches (WB in Plate $V, 6)$, one is visible in this specimen.

$\mathrm{K} 5399$ is a stem portion $170 \mathrm{~mm}$ long, $76 \times 88 \mathrm{~mm}$ in diameter with a pith cavity of $9 \times 11 \mathrm{~mm}$ surrounded by 68 vascular segments. Two woody branch scars are present, one hidden below the sandstone cover, another measuring $8 \times 10 \mathrm{~mm}$. Nodes are not visible on the outer stem surface, one additional branch scar measures approximately $7 \times 7 \mathrm{~mm}$. The transverse section reveals several "growth interruptions", which are also visible on the eroded surface.

$\mathrm{K} 5400$ is another stem portion, cut obliquely at an angle of $\mathrm{ca} 35^{\circ}$ to the stem axis. The transverse section shows distinct "growth interruptions", also accentuated on the eroded surface. Two nodes are recognisable separated by. ca $50 \mathrm{~mm}$ and bear several branch traces, $6-16 \mathrm{~mm}$ in diameter. Although quite similar in overall appearance to $\mathrm{K} 5266$ and $\mathrm{K} 5455$, there is insufficient evidence to assign the material to one plant.
Branching system - The branching system in this species is characterised by (1) woody branches originating from secondary growth of single side branches or bifurcations of the stem forming a three-dimensionally projecting crown, and (2) by side branches departing from the nodes. These side branches can occur at every node, but usually are of variable number per node, 3-12 in the present material. Side branches are recognisable as branch scars at the outer stem surface (Plate III, 1-3) or as branch traces in tangential sections (Plate II, 1-3, 6-7; Plate III, 4). Secondary growth can be present or absent in these traces or scars; in some cases individual branch traces became overgrown during stem thickening. In K 4965, branch traces/scars are elliptical averaging $5.19(4.78-5.54) \mathrm{mm}$ in height and 3.54 (2.664.13) $\mathrm{mm}$ in width (Plate II, 1-3, 6-7).

K 5266 shows three woody branches departing from the stem and probably originating from successive bifurcations of the stem, whereupon the upright stem maintained dominance. The lowermost one, $105 \mathrm{~mm}$ distant from the lower end, is $196 \mathrm{~mm}$ long and $36 \times 38 \mathrm{~mm}$ in diameter, having a small pith cavity of $4 \mathrm{~mm}$ diameter and likewise several nodes carrying abundant small branch scars. The second one, $525 \mathrm{~mm}$ above the lower end of the specimen, is $50 \mathrm{~mm}$ long and $22 \mathrm{~mm}$ in diameter. The third branch, $1125 \mathrm{~mm}$ from the lower end, is ca $30 \mathrm{~mm}$ long and $32 \mathrm{~mm}$ in diameter. Additionally, K 5266 bears numerous irregular positioned branch scars or traces of variable size reaching 2-27 mm in diameter (Plate III, 1-6; Plate IV, 1-2, 4, 6-7).

Anatomy of primary tissues - Carinal canals in K 4965 are elliptical averaging 290 (180-420) $\mu \mathrm{m}$ radially and 210 (140-290) $\mu \mathrm{m}$ tangentially, and are surrounded by several rows of circular to polygonal metaxylem elements, 49 (13-120) $\mu \mathrm{m}$ in diameter (Plate I, 6), with annular thickenings (Plate II, 4). In K 5266, carinal canals are collapsed; surrounding metaxylem elements average $39 \mu \mathrm{m}(20-54)$ in diameter (Plate III, 7).

Anatomy of secondary tissues - In transverse section, a clear distinction between interfascicular rays and fascicular wedges is only visible within the innermost wood (Plate I, 7; Plate III, 7); it becomes less obvious more distally (Plate I, 5; Plate III, 5). However, in longitudinal tangential section the segmentation of the secondary body is still recognisable and continues from node to node (Plate II, 7; Plate IV, 4). 
Nevertheless, in the description chart, ray parenchyma is characterised without any assignment to interfascicular or fascicular rays.

In $\mathrm{K} 4965$, wood thickness ranges between 25 and $89 \mathrm{~mm}$. At the base, and $300 \mathrm{~mm}$ above the base, the secondary body consists of 55 primary vascular bundles or fascicular wedges (Plate I, 4: section A); $1470 \mathrm{~mm}$ above the base, 76 fascicular wedges are recognisable (Plate I, 3: section B); and at the top of the stem portion, 84 fascicular wedges surround the pith (Plate I, 2: section C), revealing part of the epidogenetic phase of the plant development. In transverse section, interfascicular rays and fascicular wedges are clearly distinguishable up to $10-15 \mathrm{~mm}$ from the pith periphery (Plate I, 6; Plate III, 7), because tracheid files became intercalated in the proximal interfascicular rays very early in ontogenetic development (Plate I, 7). In the innermost wood, fascicular wedges are composed of up to 27 cell files averaging $0.69(0.45-0.88) \mathrm{mm}$ in width. Tracheids are square to rectangular averaging initially 41 (30-70) $\mu \mathrm{m}$ radially and 30 (22-50) $\mu \mathrm{m}$ tangentially, in the distal wood 55 (40-70) $\mu \mathrm{m}$ radially and 46 (20-70) $\mu \mathrm{m}$ tangentially (Plate I, 5). Rays are composed of 3-10 parenchyma rows, 204 (100-340) $\mu \mathrm{m}$ wide in the inner wood with rectangular cells averaging 135 (50-210) $\mu \mathrm{m}$ radially and 31 (18-70) $\mu \mathrm{m}$ tangentially (Plate I, 6-7), and in the outer wood rays averaging 292 (190520 ) in width. In both K 4965 and K 5266, ray parenchyma cells commonly bear circular pits in the horizontal walls (Plate II, 5; Plate IV, 5), although pristine anatomical preservation is required to recognise this character.
K 5266 has a maximum wood thickness of $36 \mathrm{~mm}$, several growthring-like concentric tissue density variations are recognisable throughout the wood (Plate III, 5-6).

In radial section, secondary xylem tracheids have exclusively scalariform pitting in their radial walls (Plate II, 4; Plate IV, 8). In K 4965, 16 pits occur per $100 \mu \mathrm{m}$ vertical distance (Plate II, 4). Interfascicular rays are composed of rectangular parenchymatous cells, averaging 89 (50170) $\mu \mathrm{m}$ axially and 108 (73-140) $\mu \mathrm{m}$ radially.

In tangential section, the high portion of parenchyma is most conspicuous, with the secondary body composed of at least 35\% of parenchyma (Plate II, 7; Plate IV, 4). In K 4965, tracheids are several millimetres long. Parenchymatous cells of interfascicular rays average 70 (30-170) $\mu \mathrm{m}$ axially and $39 \mu \mathrm{m}(10-70) \mu \mathrm{m}$ tangentially.

Leaf traces - In nodal position, closely beneath the branch traces, small elliptical leaf traces were recognised. They measure 1.36 (1.11$1.61) \mathrm{mm}$ in height and $0.43(0.29-0.56) \mathrm{mm}$ in width (Plate II, 6-7; Plate IV, 4; Plate V, 3, 9).

Extraxylary, cortical tissues and periderm - Due to transport abrasion the external surface of the specimens lacks any extraxylary tissues. Arthropitys barthelii sp. nov. Neregato, Rößler et Noll

Holotype: K 5787.

Additional material: K 4874, K 5500, K 6040.

Type locality: Tocantins Fossil Trees Natural Monument (TFTNM), Parnaíba Basin, central-north Brazil.

Type stratum: Motuca Formation, Permian.

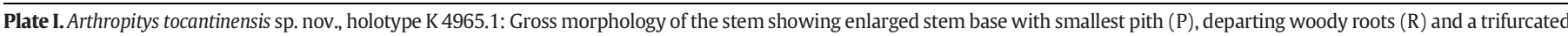

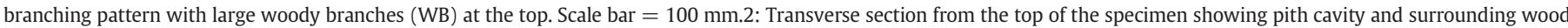

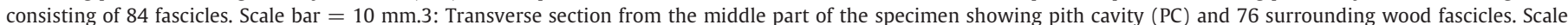

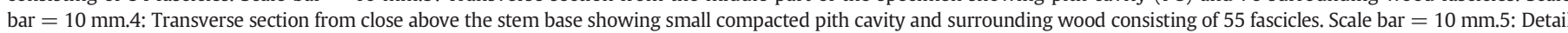

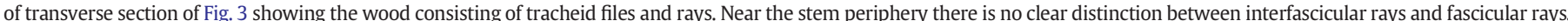

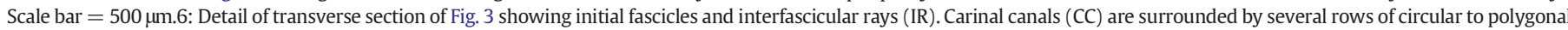

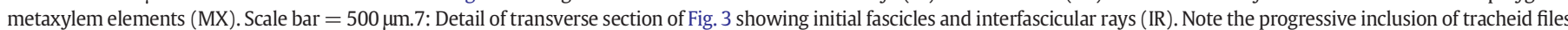
(arrow) close to the pith margin leading to a rather homogeneous wood without clear segmentation. Scale bar $=200 \mu \mathrm{m}$.

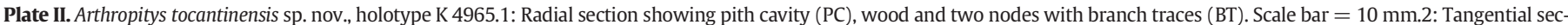

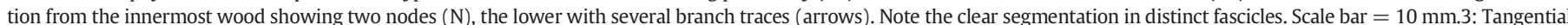

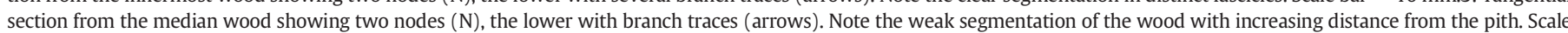

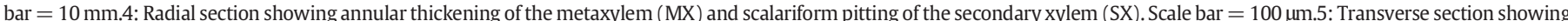

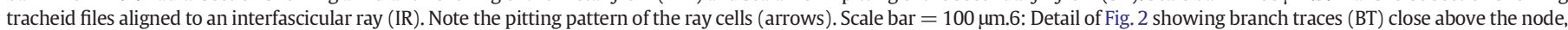

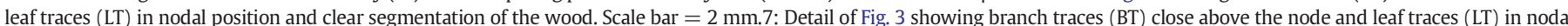
position. Note the weak segmentation of the wood and the initial secondary growth of the branch trace. Scale bar $=2 \mathrm{~mm}$. (see on page 42 )

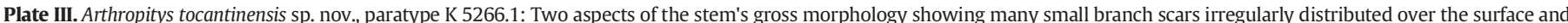

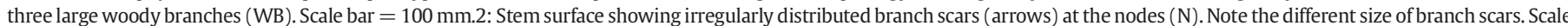

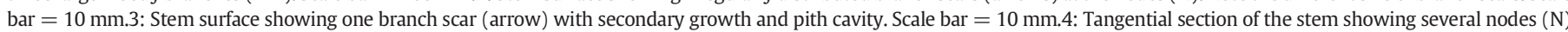

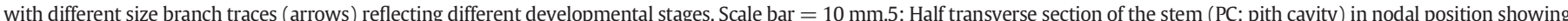

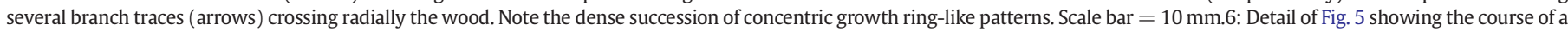

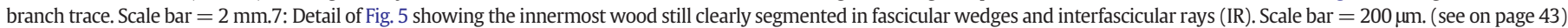

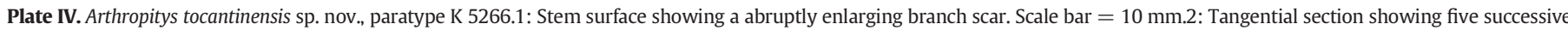

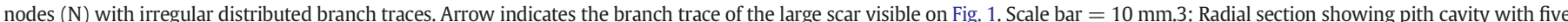

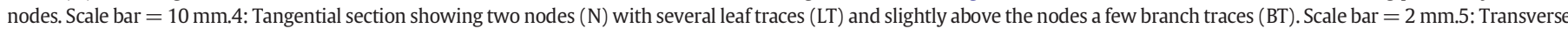

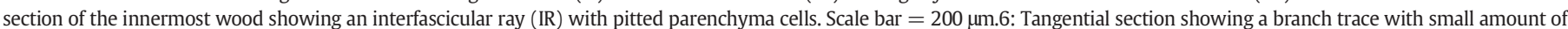

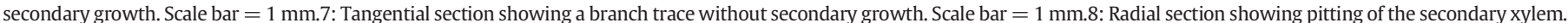
Scale bar $=100 \mu \mathrm{m}$. (see on page 44 )

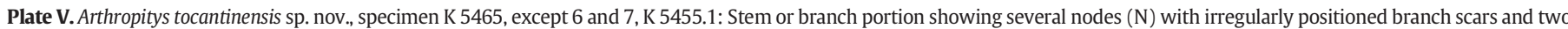

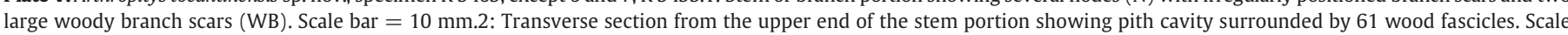

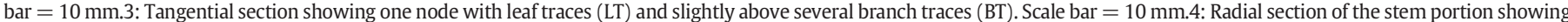

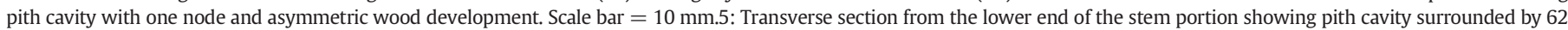

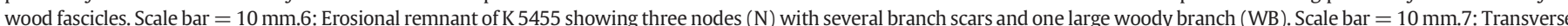

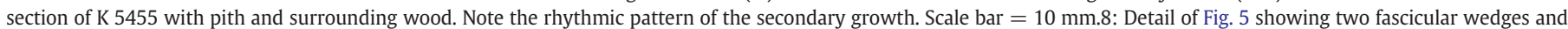

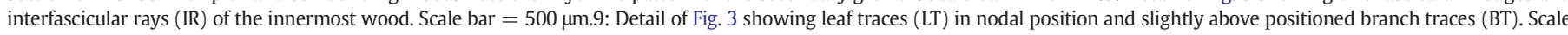
bar $=1 \mathrm{~mm}$. (see on page 45$)$

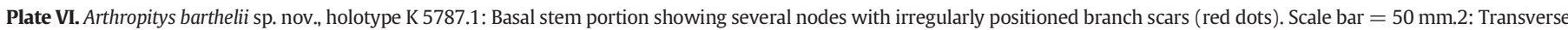

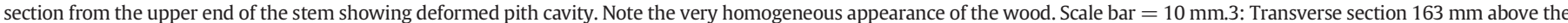

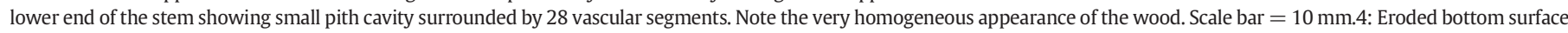

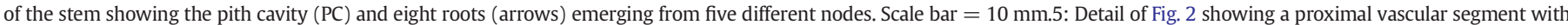

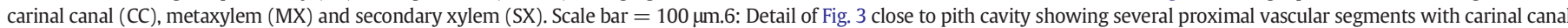

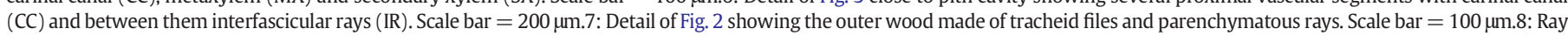
parenchyma showing small circular pits (arrows) in their horizontal walls. Scale bar $=100 \mu \mathrm{m}$. (see on page 46) 


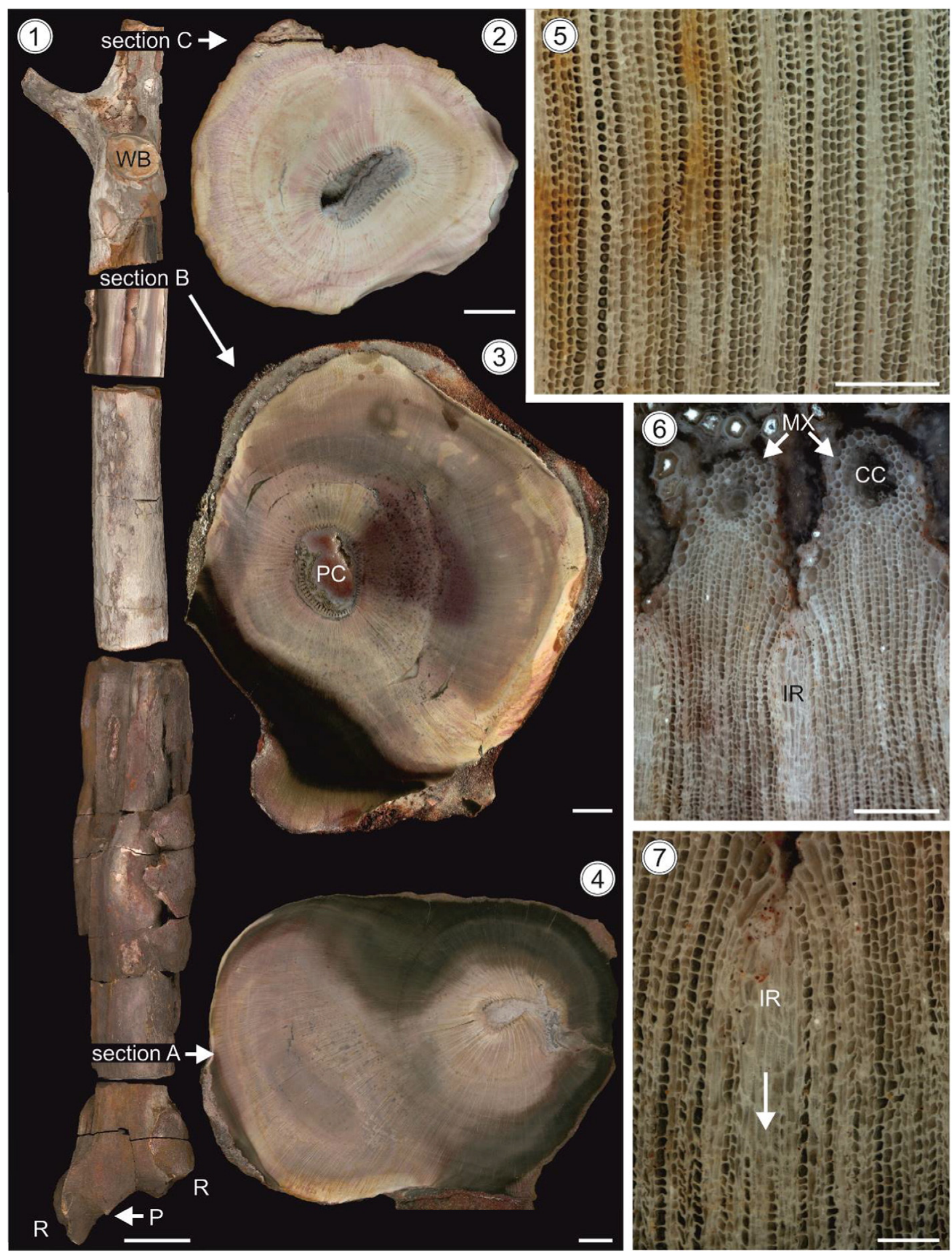



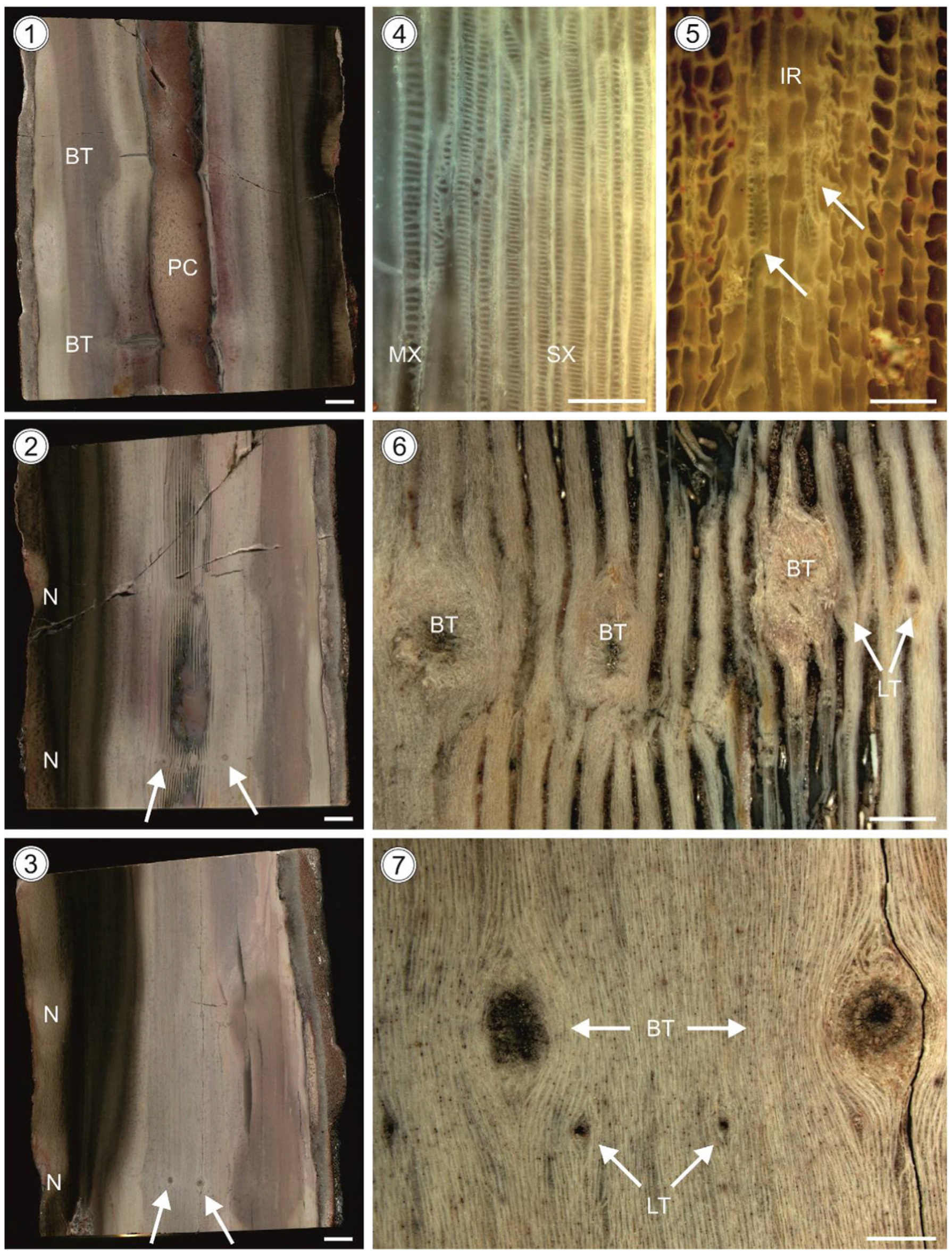

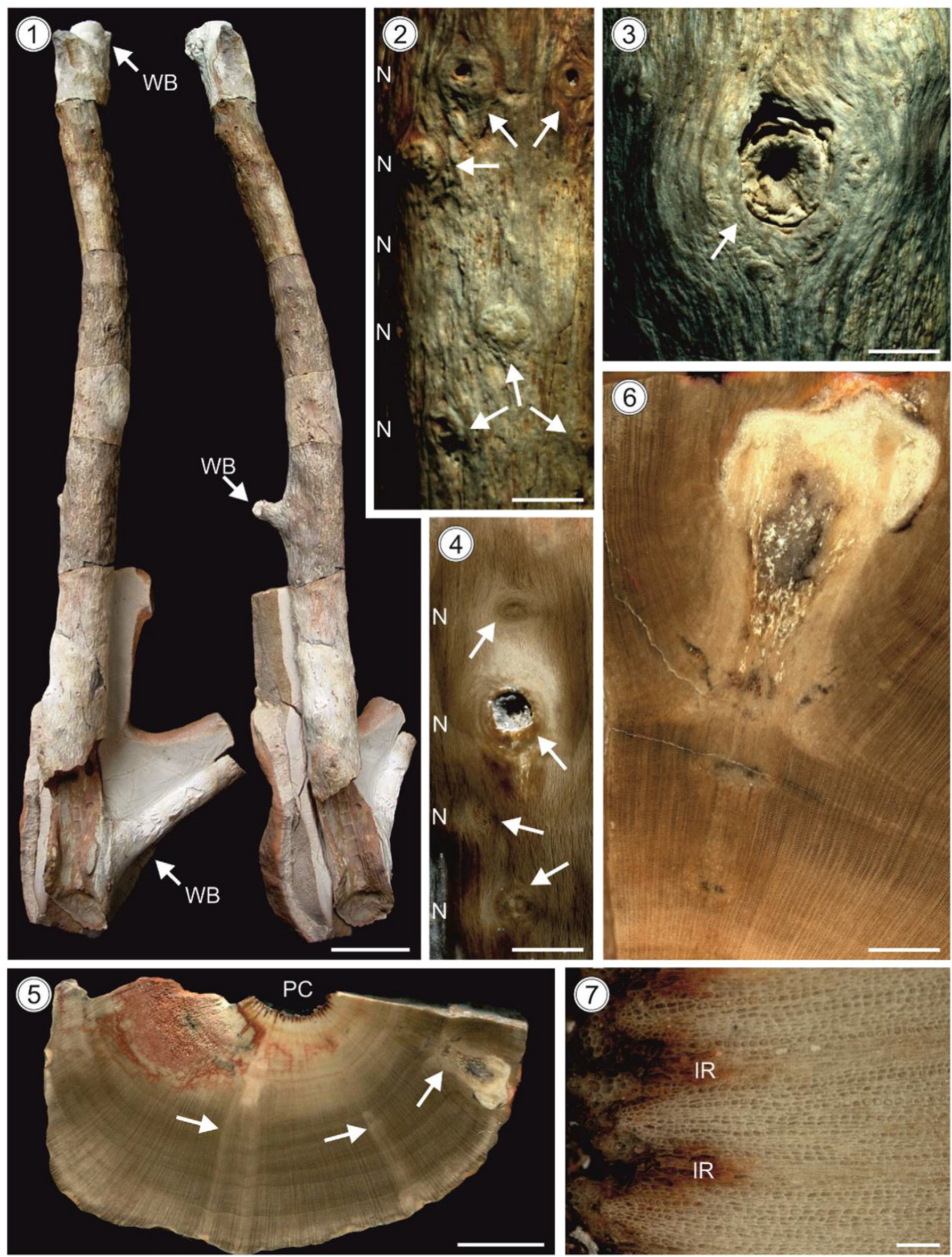

Plate III (caption on page 40 ) 

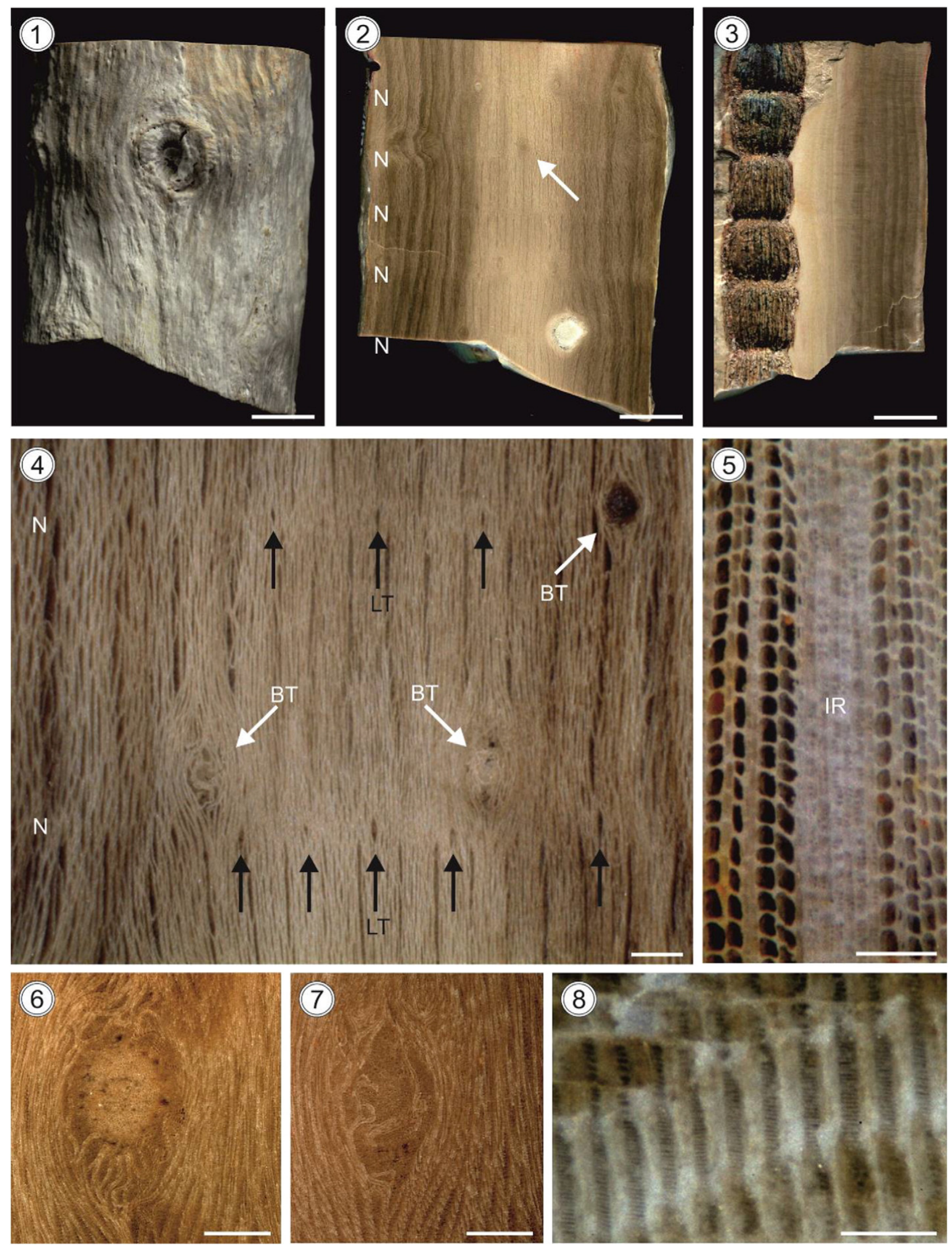


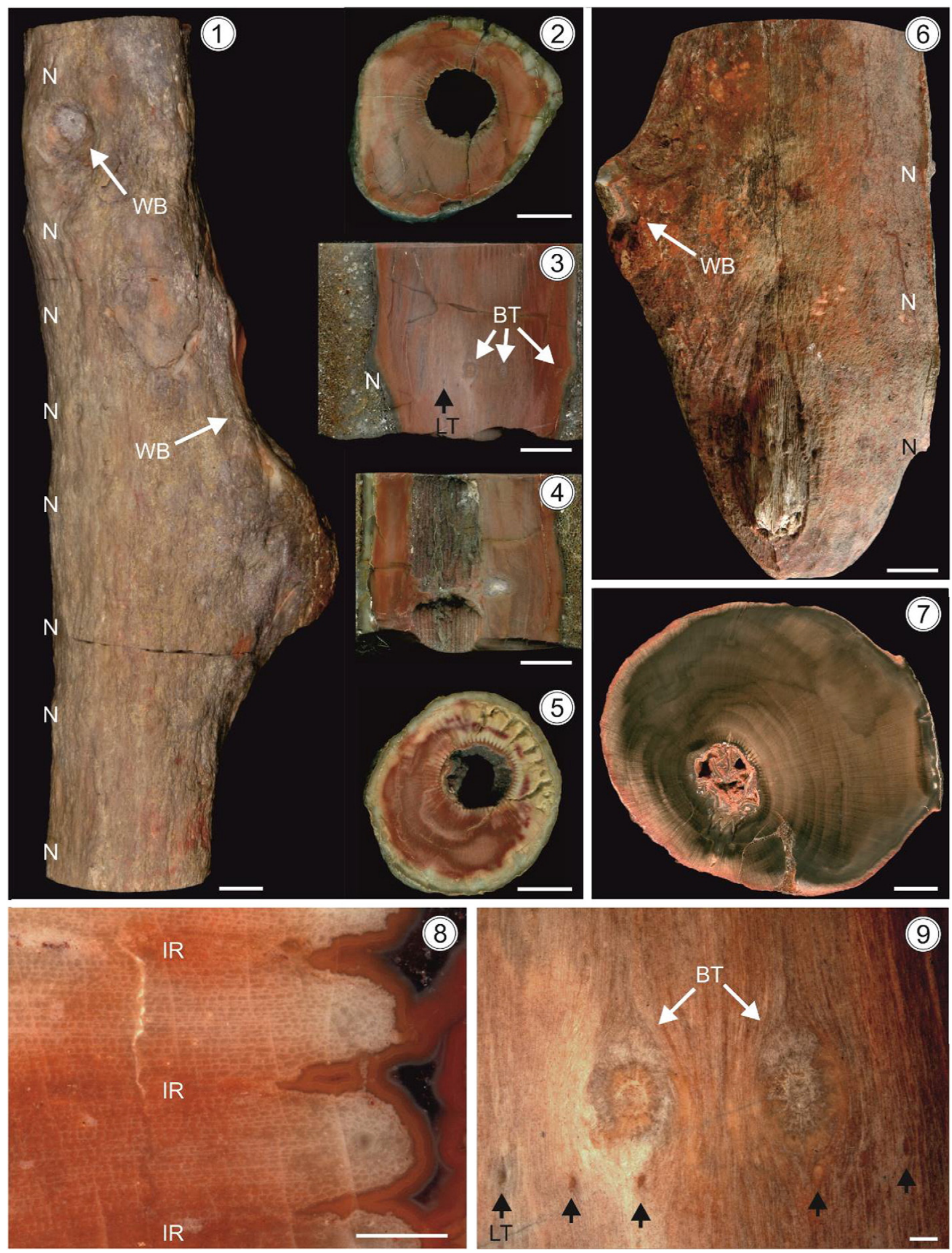




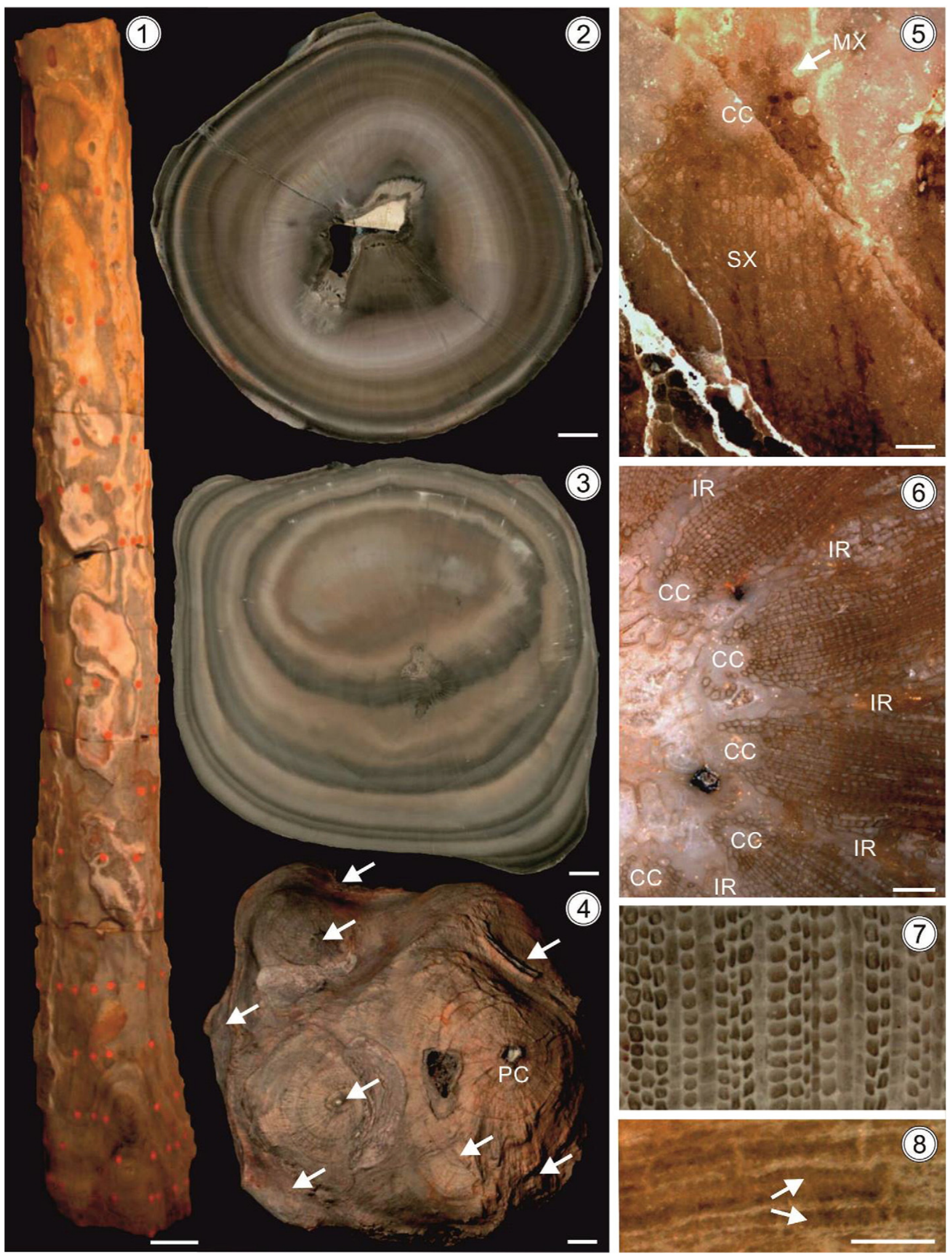



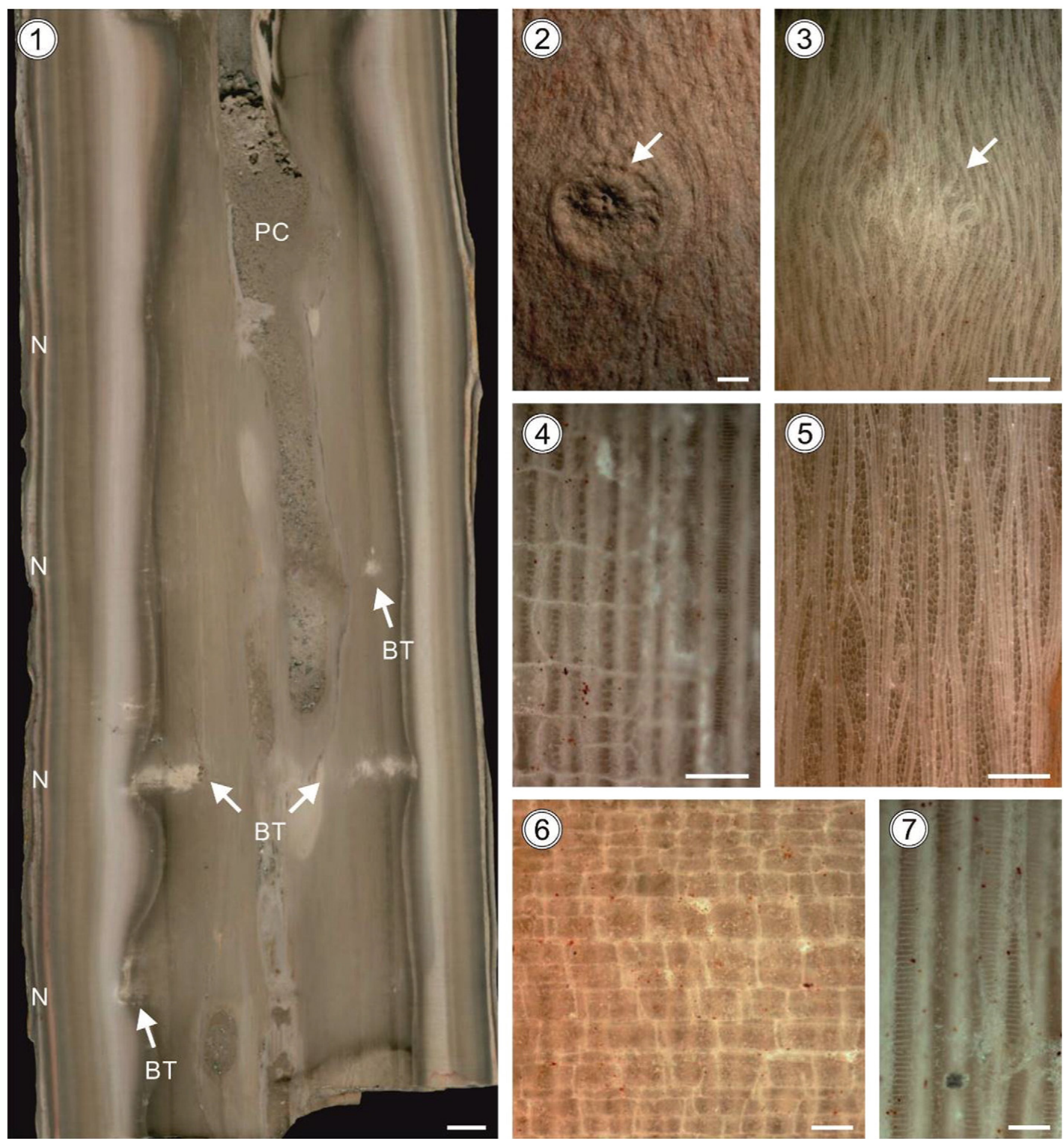

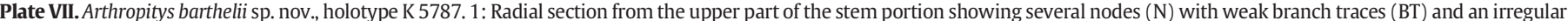

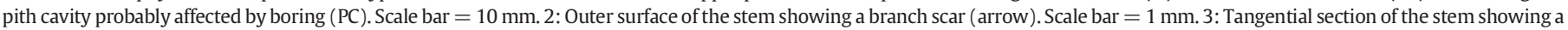

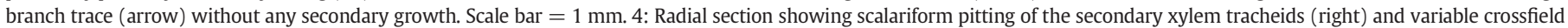

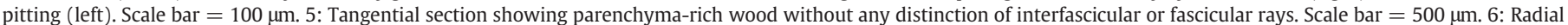
section showing brick-shaped cells of a parenchymatous ray. Scale bar $=100 \mu \mathrm{m}$. 7: Radial section showing scalariform pitting of the secondary xylem. Scale bar $=50 \mu \mathrm{m}$.

Etymology: The specific name is dedicated to our friend, palaeobotanist Prof. Dr. Manfred Barthel, Berlin, in recognition of his encouraging work on late Paleozoic floras and terrestrial ecosystems in general.

Diagnosis: This species presents 2-17 side branches at every node; side branches lack secondary growth and are disposed in irregular pattern. Homogeneous wood without distinct interfascicular rays and fascicular wedges, except within the first few millimetres of the secondary body. Secondary xylem tracheids have only scalariform pitting. Circular to broad-oval pitting is present in crossfield areas. Ray parenchyma with pitted horizontal walls. 1-3 irregularly arranged first-order roots depart from the lowermost nodes and show secondary growth.

Remarks: Although pith diameters usually change during the ontogenetic development of the plant and are therefore regarded as of 
minor diagnostic value, it is striking that the pith cavity in this species is very narrow in all investigated specimens irrespective of the amount of secondary growth. However, only in one case can we prove that a specimen is a lower stem portion based on the presence of root scars.

Description

General morphology - The holotype, K 5787, represents a portion of a basal stem, $1280 \mathrm{~mm}$ long, found as an abraided remnant in wellrounded, well-sorted, medium-grained quartz sandstone (Plate VI, 1). The stem's basal diameter is $150 \times 180 \mathrm{~mm}$; girth is $502 \mathrm{~mm}$; slightly tapering upward and the enlarged base of the trunk has a pith cavity of $2.8 \times 4.8 \mathrm{~mm}$ surrounded by 25 vascular segments; $88 \mathrm{~mm}$ distant from the lower end, the pith is surrounded by 28 vascular segments; at $163 \mathrm{~mm}$ above the lower end, the pith cavity is surrounded by 28 vascular segments (Plate VI, 3). At the upper end, the stem measures $104 \times 114 \mathrm{~mm}$, girth of $340 \mathrm{~mm}$ with a deformed pith cavity (Plate VI, 2 ). The ratio between pith cavity and stem diameter along the stem equals $1: 15-30$. The mean internode length is $57(40-80 \mathrm{~mm} ; \mathrm{n}=21$ ).

Root system - The root system is composed of eight circular to oval first-order roots emerging vertically to slightly obliquely downward from several basal nodes; one from the lowermost node, three from the second node, two from the fourth node, one from the fifth node and one from the seventh node above the base (Rößler et al., 2014) (Plate VI, 4). Although nodes three and six bear several mm-size scars, no woody roots are preserved. Other nodes also bear several additional mm-sized scars, e.g., node number four hosts 23 additional scars. The distance between the lowermost node to the seventh node is $25 \mathrm{~cm}$. From the eighth node upward, only mm-size scars are recognisable, which may represent scars of former side branches (leafy twigs). The lowermost internodes are $30-35 \mathrm{~mm}$ apart. Above the sixth node, internodes increase gradually in length. The roots measure $30-52 \mathrm{~mm}$ in diameter and contain considerable secondary xylem surrounding small circular piths. Growth-ring-like concentric density variations of the secondary xylem are visible both in the trunk wood (Plate IX, 3) and in the roots (Plate $\mathrm{VI}, 4$ ) and may denote seasonal changes in the environment. In these levels, the wood tracheids have reduced diameters, but the parenchymatous cells of the rays remain not only unaffected, they broaden slightly.

Branching system - In this species, the branching system is very distinct, 2-17 branches per node have been recognised, usually occurring at every node, without any secondary growth, irregularly distributed (Plate VI, 1). Branch traces/scars point to small and delicate side branches (Plate VII, 2; Plate VIII, 3), in some cases overgrown during stem enlargement and, therefore, indistinct on the stem surface or on the radial/tangential section (Plate VII, 1, 3; Plate VIII, 1). Minimum tangential distance between neighbouring branch traces is $14 \mathrm{~mm}$.

Anatomy of primary tissues - In K 5787, carinal canals reach 160 (120-210) $\mu \mathrm{m}$ radially and $140(100-170) \mu \mathrm{m}$ tangentially, surrounded by circular to polygonal metaxylem elements averaging $34(10-70) \mu \mathrm{m}$ in diameter (Plate VI, 5, 6). A conspicuous character is the very small pith, which not significantly enlarges upwards (Plate VI, 2, 3; Plate VIII, 2).

Anatomy of secondary tissues - The secondary body - quite unusual for calamitaleans - is characterised by a conspicuous homogeneous appearance. Rays become crowded very early between tracheid files to form a rather loose homogeneous wood (Plate VI, 2, 3; Plate VIII, 2). A few millimetres centrifugally from the primary tissues, a clear differentiation between interfascicular rays and fascicular wedges is not possible (Plate VII, 5; Plate VIII, 7), even in tangential section. Nevertheless, weak growth interruptions recognised in transverse section point to some kind of seasonality in the environment.

In $\mathrm{K} 5787$, the secondary body ranges is $42-104 \mathrm{~mm}$ thick. The innermost wood fascicles consist of 1-3 tracheid rows and 1-3 intermediary parenchymatous rays averaging $0.48(0.32-0.74) \mathrm{mm}$ (Plate VI, 5 , $6)$. In the innermost wood, tracheids are circular to rectangular, reaching 45 (30-68) $\mu \mathrm{m}$ radially and 37 (15-45) $\mu \mathrm{m}$ tangentially. In the median wood, tracheids average 55 (47-69) $\mu \mathrm{m}$ radially and 46 (35-60) $\mu \mathrm{m}$ tangentially. In the outer wood, 1-7 joint tracheid rows are evident confined by rays (Plate VI, 7). Interfascicular rays, only visible in the innermost part, measure $201(100-420) \mu \mathrm{m}$ in width and consist of 1-6 rectangular parenchymatous cells reaching $102(55-220) \mu \mathrm{m}$ radially and 40 (20-85) $\mu \mathrm{m}$ tangentially. Parenchymatous cells are pitted in their horizontal walls (Plate VI, 8).

Secondary xylem tracheids have exclusively scalariform pitting with 11-16 pits per $100 \mu \mathrm{m}$ (Plate VII, 4, 7; Plate VIII, 5). Thickenings fork sporadically, especially close to the tracheid termini. Circular to broadly oval irregular pitting with 5-9 pits per $100 \mu \mathrm{m}$ is present in crossfield areas (Plate VII, 4; Plate VIII, 6). In K 5787, tracheids measure several millimetres in length. Rays consist of brick-shaped parenchymatous cells, reaching 92 (50-220) $\mu \mathrm{m}$ axially and 109 (65-220) $\mu \mathrm{m}$ radially (Plate VII, 6).

In tangential section, the secondary wood mass is composed of approximately $40 \%$ parenchyma (Plate VII, 5; Plate VIII, 7). In K 5787, parenchymatous cells of the interfascicular rays (only innermost wood) are rectangular and measure $84(40-130) \mu \mathrm{m}$ axially and $43(20-70) \mu \mathrm{m}$ tangentially (Plate VII, 5).

Extraxylary cortical tissues and periderm are not preserved.

Additional material - K 5550 is a stem portion, $138 \mathrm{~mm}$ long, $102 \times 120 \mathrm{~mm}$ in diameter, pith not completely preserved but approximately $3 \mathrm{~mm}$ in diameter (Plate VIII, 2). Nodes and branch scars are barely visible at the stem surface; in tangential view, one branch trace lacking secondary growth is recognisable (Plate VIII, 3). Secondary xylem has scalariform pitting (Plate VIII, 5) and variable broadly oval crossfield pitting (Plate VIII, 6). The wood is very homogeneous and parenchyma-rich; vascular segments only visible a few millimetres distally of the internal wood. Because it is not possible to differentiate interfascicular rays and fascicular rays, both are designated as parenchymatous rays (Plate VIII, 4, 7).

$\mathrm{K} 6040$ is represented by one slice of a stem $11 \mathrm{~mm}$ thick and $116 \mathrm{~mm}$ in maximum diameter; a cavity within the pith resulting from herbivore damage, since clusters of small coprolites are visible at the interface of the pith cavity/internal wood (Plate IX, 1-2). At least 30 Sphenophyllum axes of various ontogenetic stages (Plate IX, 4, 5) and many small roots have been preserved in the calamite interior. This interesting interaction was probably established after animal boring damage of the calamite providing a special microhabitat that sheltered the development of many Sphenophyllum axes. Preservation of the latter is quite detailed including primary and secondary vascular tissues, multilayered cortex, epidermal layer, attached leaves and roots

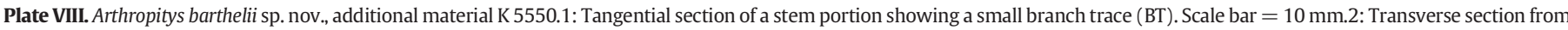

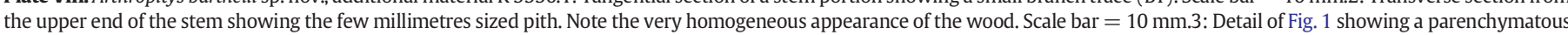

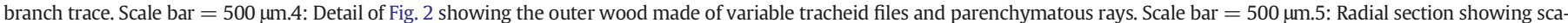

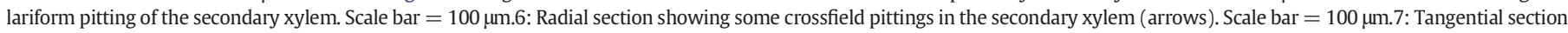
showing parenchyma-rich wood without any distinction of interfascicular rays and fascicular wedges. Scale bar $=500 \mu \mathrm{m}$.

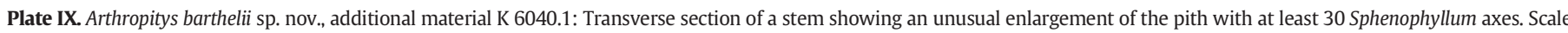

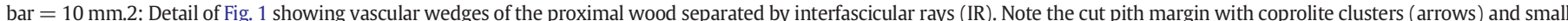

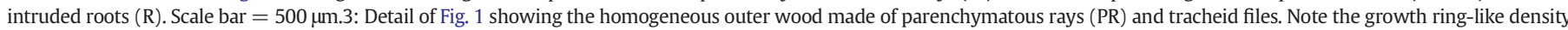

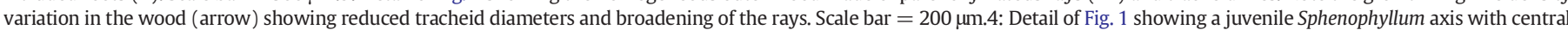

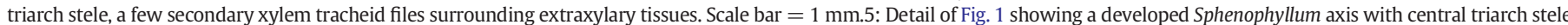

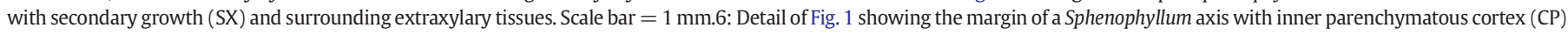
an outer sclerenchymatous cortex (CS) and an attached leaf (arrow). Scale bar $=500 \mu \mathrm{m}$. (see on page 50) 

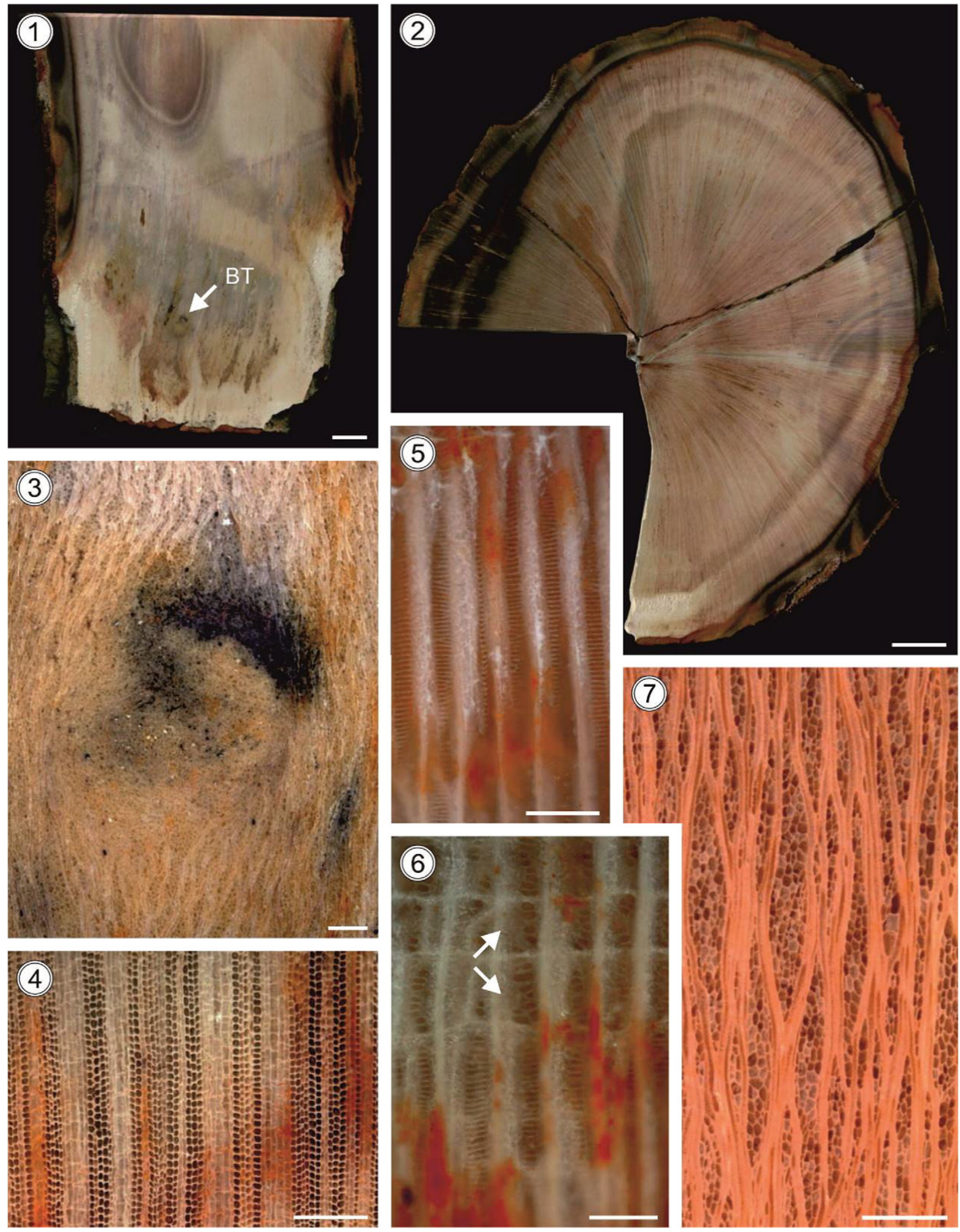

Plate VIII (caption on page 48). 

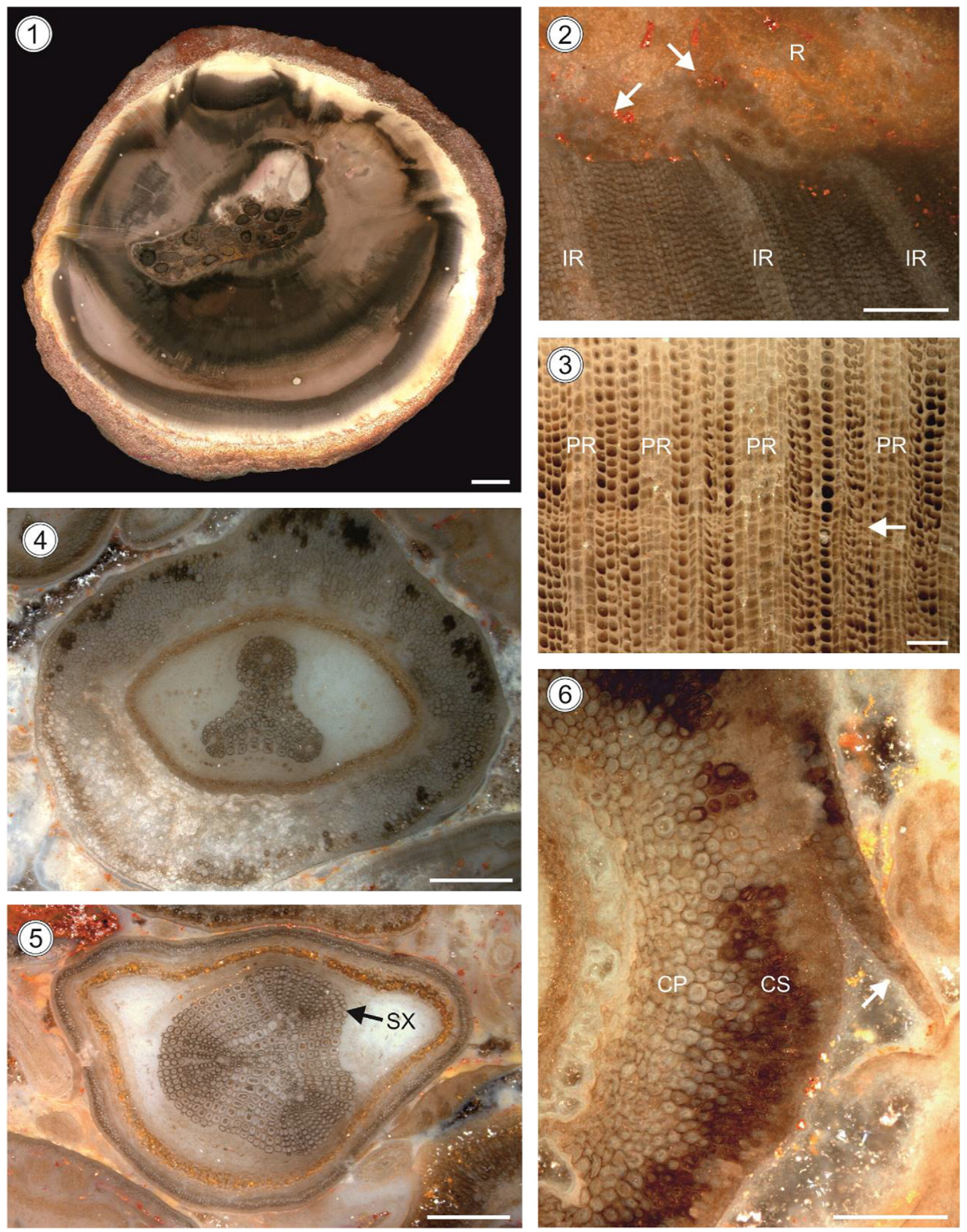

Plate IX (caption on page 48). 
(Plate IX, 4-6). Detailed description of this fossil Sphenophyllum plant is beyond the scope of this study and will be given in a forthcoming paper. The wood of $\mathrm{K} 6040$ is homogeneous without clear segmentation in fascicular wedges and interfascicular rays. A few growth ring-like density variations within the wood indicate seasonal or environmental changes (Plate IX, 3). Depending on the size of the specimen, the branch system may not be recognisable, but the sum of all other characters suggests specific assignment to $A$. barthelii sp. nov.

$\mathrm{K} 4874$ is a stem portion $175 \mathrm{~mm}$ long and $106 \mathrm{~mm}$ in maximum diameter. The pith cavity measuring $4 \times 5 \mathrm{~mm}$ is surrounded by 39 vascular segments. The secondary body has the same kind of homogeneous wood and shares anatomical characters with the aforementioned specimens.

\section{Discussion}

4.1. Comparisons of Arthropitys tocantinensis sp. nov. with previously described species

The studied specimens differ from Arthropitys kansana Andrews, 1952, Arthropitys illinoensis Anderson, 1954, Arthropitys sterzelii Rößler and Noll, 2010, and Arthropitys cacundensis Mussa and Coimbra, 1984 (in Coimbra and Mussa, 1984), in possessing exclusively scalariform pitting in the secondary xylem, whereas the other species have multiseriate circular pitting; Arthropitys iannuzzii Neregato et al., 2015 has multiseriate circular pitting and only few tracheids with scalariform pitting. Additionally, the branching system of the studied specimens is different from that of the aforementioned species.

Arthropitys bistriata (Cotta) Goeppert emend. Rößler et al., 2012, Arthropitys communis (Binney) Renault, 1896, Arthropitys lineata Renault, 1896, Arthropitys versifoveata Anderson, 1954, Arthropitys deltoides Cichan and Taylor, 1983, Arthropitys junlianensis Wang et al., 2003, Arthropitys yunnanensis (Tian and Gu) Wang et al., 2006, and Arthropitys ezonata Goeppert emend. Rößler and Noll, 2006 have, as the new species described here, scalariform pitting in their secondary xylem; Arthropitys isoramis Neregato et al., 2015 has both scalariform and multiseriate circular pitting, but all species cited above differ essentially in their branching system.

As a result, our new specimens are distinct from all Arthopitys species previously known and, therefore, they are classified as a new species, Arthropitys tocantinensis sp. nov. (see Tables 1 and 3, Fig. 2).

\subsection{Comparisons of Arthropitys barthelii sp. nov. with previously described} species

The studied specimens differ from Arthropitys gigas (Brongniart) Renault, 1896, Arthropitys kansana Andrews, 1952, Arthropitys illinoensis Anderson, 1954, Arthropitys cacundensis Mussa and Coimbra, 1984 (in Coimbra and Mussa, 1984), and Arthropitys sterzelii Rößler and Noll, 2010, with regard to their anatomy. The new material has exclusively scalariform thickening/pitting in their secondary xylem tracheids, whereas the other species bear multiseriate circular pitting; in Arthropitys iannuzzii Neregato et al., 2015, few tracheids has scalariform pitting but the majority of them shows multiseriate circular pitting. Moreover, the new material exhibits a different branching pattern in comparison to the species cited above.

The studied specimens are similar to Arthropitys bistriata (Cotta) Goeppert emend. Rößler et al., 2012, Arthropitys communis (Binney) Renault, 1896, Arthropitys lineata Renault, 1896, Arthropitys versifoveata Anderson, 1954, Arthropitys deltoides Cichan and Taylor, 1983, Arthropitys junlianensis Wang et al., 2003, Arthropitys yunnanensis (Tian and Gu) ex Wang et al., 2006, Arthropitys ezonata (Goeppert) emend. Rößler and Noll, 2006, regarding the scalariform pitting in the secondary xylem, however, the new specimens can be easily distinguished by their different branching patterns. Arthropitys isoramis Neregato et al., 2015, shows very regular branches, mostly 4 (rarely 3 ) per node, and presents both scalariform and multiseriate circular pitting on its tracheid's radial walls.

Considering these differences, the specimens studied here are distinct from all previously known species of Arthropitys and, therefore, classified as a new species, Arthropitys barthelii sp. nov. (see Tables 2 and 3, Fig. 3).

Table 1

Overview of the main anatomical and morphological data obtained from the holotype specimen of Arthropitys tocantinensis sp. nov.

\begin{tabular}{|c|c|c|c|c|}
\hline \multicolumn{5}{|c|}{ Arthropitys tocantinensis sp. nov. } \\
\hline Part of the plant & Length & Diameter stem & Diameter pith & Girth \\
\hline Stem & $1850 \mathrm{~mm}$ & $130 \times 213 \mathrm{~mm}$ at base & $2 \times 9 \mathrm{~mm}$ at base & $554 \mathrm{~mm}$ at base \\
\hline & & $52 \times 62 \mathrm{~mm}$ at top & $9 \times 20 \mathrm{~mm}$ at top & $180 \mathrm{~mm}$ at top \\
\hline Morphology/branching & \multirow{2}{*}{\multicolumn{2}{|c|}{$\begin{array}{l}\text { Branch system } \\
3-12 \text { branches at every node with and without secondary growth }\end{array}$}} & Leaf traces & Root traces \\
\hline & & & $\begin{array}{l}1.36(1.11-1.61) \mathrm{mm} \text { height } / 0.43 \\
(0.29-0.56) \mathrm{mm} \text { wide, in nodal position } \\
\text { beneath branch traces }\end{array}$ & $\begin{array}{l}\text { Departing at stem } \\
\text { base with secondary } \\
\text { growth }\end{array}$ \\
\hline Internode length & $63 \mathrm{~mm}$, barely visible & & & \\
\hline \multirow[t]{3}{*}{ Primary tissues } & Vascular strand number & \multirow{3}{*}{$\begin{array}{l}\text { Carinal canals (transverse section) } \\
\text { radially/tangentially }(\mu \mathrm{m}) \\
290(180-240) / 210(140-290) \\
\text { elliptical }\end{array}$} & Px tracheids/tyloses & \multirow{3}{*}{$\begin{array}{l}\text { Mx tracheids }(\mu \mathrm{m}) \\
49(13-120) \text {, circular } \\
\text { to polygonal }\end{array}$} \\
\hline & 55 at base & & Not preserved & \\
\hline & 84 near top & & & \\
\hline \multirow[t]{11}{*}{ Secondary tissues } & \multirow{6}{*}{$\begin{array}{l}\text { Wood } 25-89 \mathrm{~mm} \text {, fascicular wedges and } \\
\text { interfascicular rays only visible at pith } \\
\text { periphery }\end{array}$} & \multirow{6}{*}{$\begin{array}{l}\text { Fascicular wedges width }(\mu \mathrm{m}), \\
\text { number files per fascicle } \\
\text { (transverse section) } \\
\text { Initially: } 0.69(0.45-0.88) \mathrm{mm}, 27 \\
\text { files; } \\
\text { Distally: only distinct initially }\end{array}$} & \multirow{6}{*}{\multicolumn{2}{|c|}{$\begin{array}{l}\text { Tracheids (radial section) } \\
\text { Scalariform thickenings } \\
\text { Radially/tangentially ( } \mu \mathrm{m}),(\text { transverse section) } \\
\text { Initially: } 41(30-70) / 30(22-50) \text {; } \\
\text { Distally: } 55(40-70) / 46(20-70)\end{array}$}} \\
\hline & & & & \\
\hline & & & & \\
\hline & & & & \\
\hline & & & & \\
\hline & & & & \\
\hline & \multicolumn{4}{|l|}{ Interfascicular rays } \\
\hline & \multirow{4}{*}{$\begin{array}{l}\text { Width }(\mu \mathrm{m}), \text { number files per fascicle } \\
\text { (transverse section) } \\
\text { Initially: } 204 \text { (100-340), 3-10 files; } \\
\text { distally: indistinct }\end{array}$} & Cells (transverse section) & Cells (radial section) & \multirow{4}{*}{$\begin{array}{l}\text { Cells (tangential } \\
\text { section) } \\
\text { Axially/tangentially } \\
(\mu \mathrm{m}) \\
70(30-170) / 39 \\
(10-70)\end{array}$} \\
\hline & & Radially/tangentially ( $\mu \mathrm{m})$ & Axially/radially $(\mu \mathrm{m})$ & \\
\hline & & $\begin{array}{l}\text { Initially: } 135(50-210) / 31 \\
(18-70)\end{array}$ & $89(50-170) / 108(73-140)$ & \\
\hline & & $\begin{array}{l}\text { Distally: indistinctly; cells pitted in } \\
\text { the horizontal walls }\end{array}$ & & \\
\hline $\begin{array}{l}\text { Cortex/periderm/special } \\
\text { characters }\end{array}$ & not preserved & & & \\
\hline
\end{tabular}




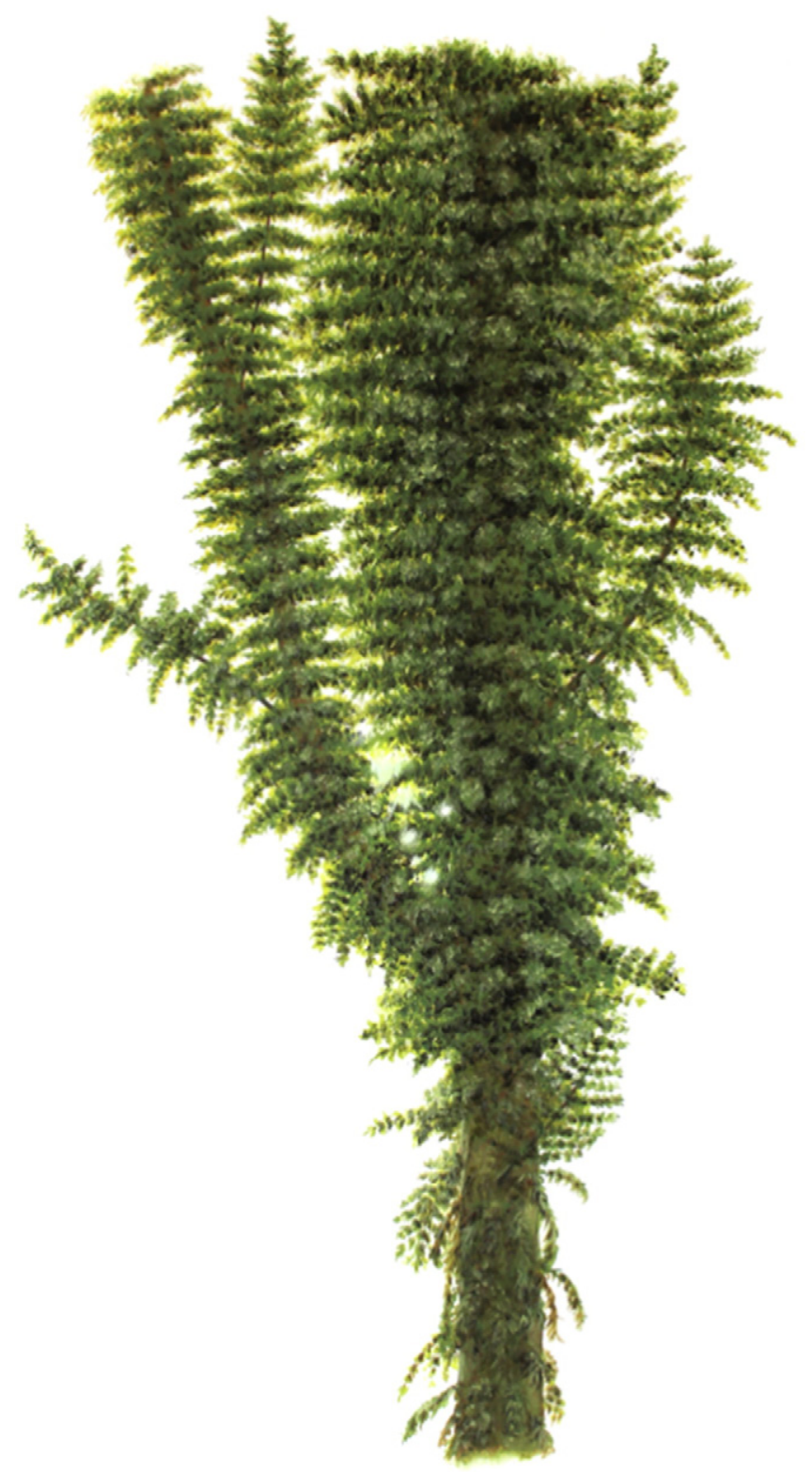

Fig. 2. Proposed reconstruction of Arthropitys tocantinensis sp. nov. Drawing: Frederik Spindler (Freiberg, Germany).

\subsection{Palaeoecological implications}

Calamitaleans are unquestionably among the most common constituents of late Paleozoic plant communities, reported from various habitats and taphonomic settings including epiclastic and pyroclastic deposits (Renault, 1893, 1896; Gastaldo, 1992; Feng et al., 2012). In some cases, they even preserved in-situ (Dawson, 1851; Grand'Eury, 1877; DiMichele and Falcon-Lang, 2011). Although various organs, such as stems, leaves, reproductive organs and roots have been studied in great detail since the early days of paleobotany, several puzzling details of calamitalean growth and fossilisation remain. In pure clastic settings, the interpretation of their fossil remains as either pith casts (as traditionally thought) or stem casts, obviously remains equivocal (DiMichele and Falcon-Lang, 2012; Thomas, 2013; Falcon-Lang, 2015). Although true stem casts may be as common as pith casts and have long been studied especially from calamitaleans entombed in finegrained pyroclastics (Petzholdt, 1841; Noll, 2000; Löcse et al., 2013; Rößler, pers. observations at ongoing Chemnitz excavations) it is challenging to address preservational circumstances and taphonomy for every site.

The siliceous petrified material from the Parnaíba Basin can contribute to this discussion in that these specimens preserved the exterior of the stems revealing morphological features on the whole-stem casts. Additionally, anatomically preserved large calamitaleans shed light on different aspects of growth and ecology. Recently, the root systems of some Permian calamitaleans were characterised including that of the here described A. barthelii sp. nov. (Rößler et al., 2014, p. 77 and textfig. 4). An interpretation differing from the reed-like, fast-growing individuals reconstructed from the Pennsylvanian palaeoequatorial tropics was suggested (Rößler et al., 2014). Several new species recognised in the Permian of Brazil underline an unexpected diversity in growth form among these archaic arborescent sphenophytes (Neregato et al., 2015). Despite the striking conservatism in architecture and anatomy shared with their extant relatives (Equisetum), calamitaleans reveal a considerable adaptive range expressed in their branching and anatomy (Rößler et al., 2012). Not only their remarkable tolerance of disturbance or salinity (Gastaldo, 1992; Pfefferkorn et al., 2001) but also their outstanding architectural plasticity qualified them to survive severe environmental disturbances and climatic change up to the Lopingian (DiMichele et al., 2008). Here, the broadly defined Arthropitys incorporates species exhibiting characters, such as the common pitting of ray parenchyma, never documented before in this group but surprisingly present in every new species from Brazil. Recently, we re-investigated calamitaleans represented by free-stemmed woody trees that were anchored in the soil by numerous secondary roots (Neregato et al., 2015). Not only documented in Brazil, this quite unusual pattern among pteridophytes was confirmed by huge petrified calamitaleans from the type locality of Chemnitz in eastern Germany (Rößler et al., 2014) sharing with the Brazilian specimens site-specific features too. Although preserved in quite different ways, both depositional environments are characterised by clastic substrates and low-maturity soils without any peat accumulation (Luthardt et al., 2015). In contrast to the majority of much smaller individuals from nutrient-poor peat-forming mires (e.g., Josten, 1991; Cleal and Thomas, 1994; Galtier, 1997; Barthel, 2004; Opluštil et al., 2009), the largest calamitaleans known to date, Arthropitys ezonata from Chemnitz (Rößler and Noll, 2006), $60 \mathrm{~cm}$ in maximum diameter, and Arthropitys sp. (Rößler, 2014), $40 \mathrm{~cm}$ in maximum diameter, from Filadelfia, Tocantins, thrived as long-living individuals on mineral soils in seasonally influenced fluvial environments. In this respect we recognise obvious differences from the detailed ecological analysis and implications provided by Falcon-Lang (2015), but much accordance with the conclusions of DiMichele and Falcon-Lang (2012). Ultimately, further studies will be necessary to clarify the ecology of the group. Both sites, Tocantins and Chemnitz, also yielded noteworthy interactions among calamitaleans and their neighbouring plants. In Chemnitz, Calamitea striata was found surrounded by the climbing fern Ankyropteris brongniartii and its dense mats of adventitious aerial roots (Rößler and Noll, 2007). Whereas Sphenophyllum axes as isolated remains in fossiliferous cherts were documented a decade ago from the Parnaíba Basin (Dernbach et al., 2002), we can now present a peculiar interaction between a woody calamite stem, herein assigned to Arthropitys barthelii sp. nov., and at least 30 Sphenophyllum axes. The latter intruded into the calamite's pith cavity. Conspicuously narrow in this species, the pith cavity was considerably enlarged by cutting the internal wood segments (Plate IX, 2). Small coprolites abundant at this interface may indicate the cause of damage, namely arthropod xylophagy, as previously reported for other Brazilian calamitaleans showing pathogenic tissue reaction and abundant callus development (Rößler, 2006, Fig. 8b). Anatomical preservation of the Sphenophyllum axes (Plate IX, 4-6) show the steles to have variable amounts of secondary growth reflecting a range of ontogenetic stages, a multilayered parenchymatous to sclerenchymatous cortex, and the epidermal layer with attached leaves. Hence, this example preserved a particular "life snapshot" and reveals an additional ecological interaction between 
Table 2

Overview of the main anatomical and morphological data obtained from the holotype specimen of Arthropitys barthelii sp. nov.

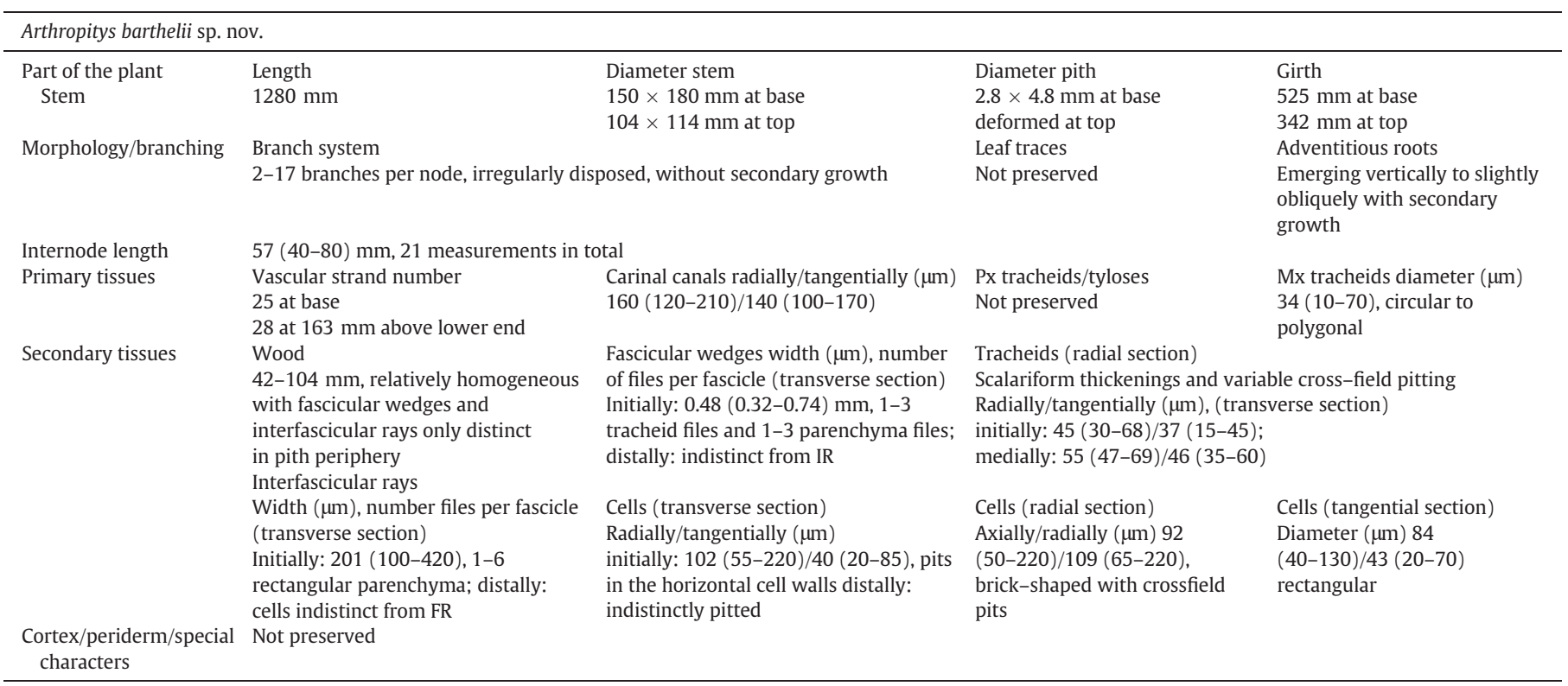

perennial arboreal sphenophytes and their surrounding supposed ground cover or climbers.

\section{Palaeophytogeographical implications}

Several palaeogeographic reconstructions of the late Paleozoic outline the collision between Gondwana and Laurasia that resulted in the Pangaea landmass. Its amalgamation created a vast C-shaped landmass extending pole to pole with the central region close to the Equator and flanked to the east by the Tethys Ocean and to the west by the Panthalassa Ocean (Blakey, 2008; Fluteau et al., 2001; Scotese and Barret, 1990; Scotese and Langford, 1995; Ziegler et al., 1997). Owing to the global geological context, the end of the Carboniferous was marked by several changes shaping the supercontinent Pangaea
(Parrish, 1995). Among these, the most relevant were: (1) The collision of Gondwana and Laurasia during the Permo-Pennsylvanian closed the equatorial epicontinental sea causing and generating active subduction along the coast being responsible for the formation of the Central Permian Mountains and for the disruption of the equatorial warm current (Ross and Ross, 1985; Tabor and Poulsen, 2008); (2) The sea level underwent changes with implications for oceanic circulation (Roscher and Schneider, 2006; Haq and Schutter, 2008); (3) The glaciation that spanned the Middle Pennsylvanian to Cisuralian was succeeded by a deglaciation process (Montañez and Poulsen, 2013). Thus, this set of factors in the late Pennsylvanian-Cisuralian was responsible for an extensive aridification of continental interiors. The climate was increasingly characterised by the transition from a cold humid climate to drier conditions, especially in Central and Western Pangaea, resulting in a

Table 3

Comparison among the type species Arthropitys bistriata, Arthropitys tocantinensis sp. nov., and Arthropitys barthelii sp. nov.

\begin{tabular}{|c|c|c|c|}
\hline & Arthropitys bistriata & Arthropitys tocantinensis sp. nov. & Arthropitys barthelii sp. nov. \\
\hline \multicolumn{4}{|l|}{ Fascicular wedges } \\
\hline & $\begin{array}{l}\text { Well defined throughout } \\
\text { the wood }\end{array}$ & $\begin{array}{l}\text { Well defined only in the innermost wood, more distally } \\
\text { homogenous appearance of the wood in transverse section, but } \\
\text { still delimited to interfascicular rays in tangential section }\end{array}$ & $\begin{array}{l}\text { Well defined only in the innermost wood, more } \\
\text { distally homogeneous appearance of the wood in } \\
\text { both transverse and tangential sections }\end{array}$ \\
\hline $\begin{array}{l}\text { Thickening/pitting in } \\
\text { secondary xylem } \\
\text { (radial tracheid } \\
\text { walls) }\end{array}$ & $\begin{array}{l}\text { Scalariform pitting, very } \\
\text { rare transitions to } \\
\text { multiseriate circular } \\
\text { pitting }\end{array}$ & Only scalariform pitting & $\begin{array}{l}\text { Only scalariform pitting; broad-oval pitting in } \\
\text { crossfield areas }\end{array}$ \\
\hline \multicolumn{4}{|c|}{ Interfascicular rays (transverse section) } \\
\hline $\begin{array}{l}\text { Throughout secondary } \\
\text { body }\end{array}$ & $\begin{array}{l}\text { - Visible throughout the } \\
\text { whole wood } \\
\text { - No indication of pitted } \\
\text { ray parenchyma }\end{array}$ & $\begin{array}{l}\text { - Visible in innermost wood, indistinct in the external wood } \\
\text { - Pitted ray parenchyma }\end{array}$ & $\begin{array}{l}\text { - Visible only in the innermost wood, distally a } \\
\text { homogeneous, parenchyma-rich wood appears } \\
\text { - Pitted ray parenchyma }\end{array}$ \\
\hline \multicolumn{4}{|l|}{ Tangential section } \\
\hline$\%$ parenchyma cells & Up to $50 \%$ & $35 \%$ & $40 \%$ \\
\hline \multicolumn{4}{|l|}{ Branching system } \\
\hline $\begin{array}{l}\text { Number of side } \\
\text { branches (leafy } \\
\text { twigs) }\end{array}$ & $\begin{array}{l}9-16 \text { per whorl (whorl at } \\
\text { every } 5 \text { th to } 9 \text { th node) }\end{array}$ & $\begin{array}{l}3-12 \text { at every node but different size of neighbouring branch } \\
\text { traces, in some cases } \\
\text { overgrown during secondary growth }\end{array}$ & $\begin{array}{l}2-17 \text { at every node, sometimes overgrown during } \\
\text { secondary growth }\end{array}$ \\
\hline $\begin{array}{l}\text { Growth type of side } \\
\text { branches (leafy } \\
\text { twigs) }\end{array}$ & $\begin{array}{l}\text { Without secondary } \\
\text { growth }\end{array}$ & Without or with little secondary growth & Without secondary growth \\
\hline Woody branches & $\begin{array}{l}\text { At least } 3 \text { orders of woody } \\
\text { branches }\end{array}$ & Woody branches present & Absent \\
\hline
\end{tabular}




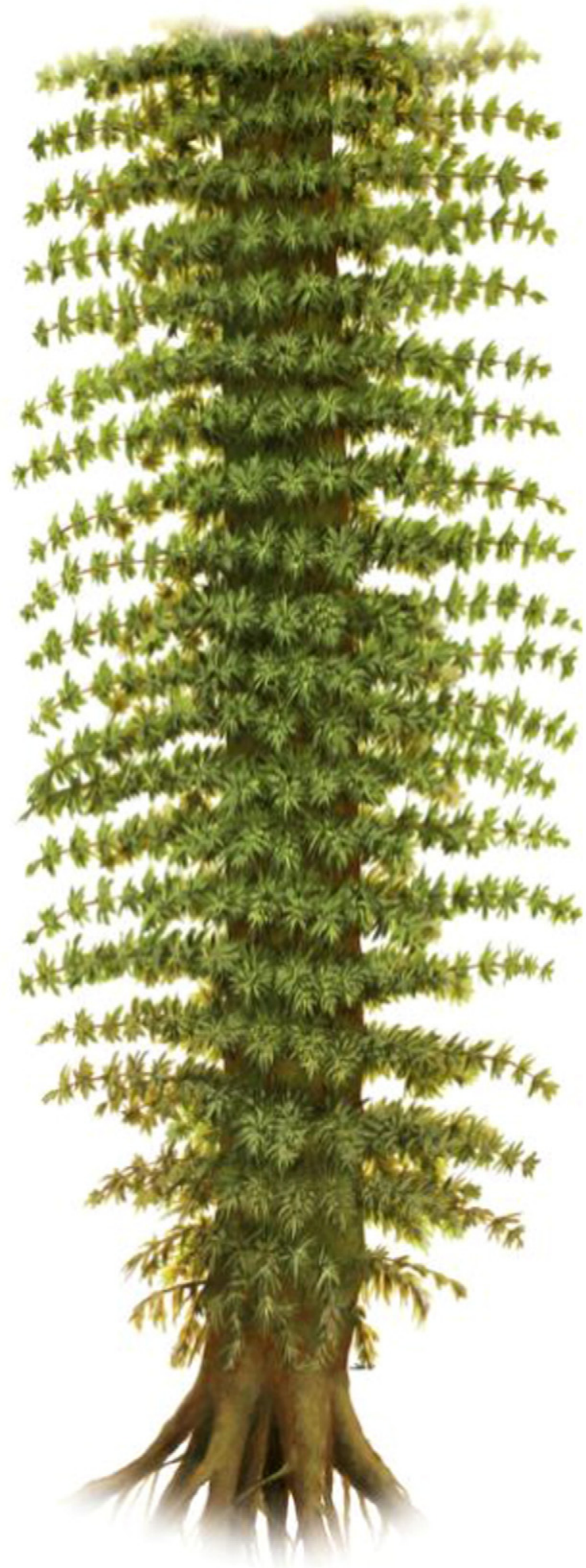

Fig. 3. Proposed reconstruction of Arthropitys barthelii sp. nov. Drawing: Frederik Spindler (Freiberg, Germany).

striking floral and faunal provincialism (Dickins, 1993; Chumakov and Zharkov, 2002; Montañez and Poulsen, 2013; Parrish, 1995; Roscher and Schneider, 2006; Tabor and Poulsen, 2008).

In the Cisuralian, the Parnaíba Basin was positioned close to $30^{\circ} \mathrm{S}$ latitude, distant from tectonically active areas and marked climatically by a seasonal monsoonal regime (Faria and Truckenbrodt, 1980; Góes and Feijó, 1994; Pinto and Sad, 1986). This context is supported by several climate-sensitive indications. Faria and Truckenbrodt (1980) described evaporites, such as gypsum deposits in the Pedra de Fogo and Motuca formations; the fern Buritiranopteris costata (Tavares et al., 2014) clearly exhibits marked xeromorphic aspects in their fronds; frequent growth interruptions to secondary wood reflecting some kind of environmental seasonality were registered in several woody plants (Rößler, 2006; Kurzawe et al., 2013a,b; Rößler et al., 2014; Benício et al., 2015). Following Neregato et al. (2015) who described prominent tissue density variations in the secondary xylem of their new species Arthropitys isoramis and $A$. iannuzzii and interpreted them as growth rings, we report further evidence of growth-ring-like patterns in additional calamitalean taxa (Arthropitys tocantinensis sp. nov. and A. barthelii sp. nov.). Another striking indication of this climatic trend is exhibited in the petrified tissues of the new species. The silicification process requires alternation of humid and dry conditions to precipitate the silica into the cell lumina and intercellular spaces (Mussa and Coimbra, 1984; Jones et al., 1998; Matysová et al., 2010).

Besides this palaeoclimatic scenario, the Parnaíba Basin was positioned between two major floristic provinces, the Euramerican in the North and the Gondwanan in the South (Fig. 4). Generally speaking, the continental biotas especially plant communities underwent pronounced modifications over times according to climatic and geographical changes (DiMichele and Aronson, 1992). As pointed out by Mussa and Coimbra (1987), interactions between the Parnaíba Basin floristic associations and the classical Gondwana associations are to be expected. Additionally, it is worthwhile investigating influences of the Euramerican and/or Cathaysian floristic associations on the Parnaíba Basin flora.

Although detailed floristic studies in the Parnaíba Basin have been carried out only in recent years, 36 species within 25 genera (Table 4) have been identified. It is important to note that fossils preserved as adpressions, such as Pecopteris (Tavares, 2011), Cyclostigma and Calamites (Iannuzzi and Scherer, 2001), lycophytes found by the authors (unpublished data), and impressions of the callipterid foliage Rhachiphyllum aff. schenkii in association with fern pinnae of Pecopteris (Iannuzzi and Langer, 2014), all found in the Pedra de Fogo Formation, were not considered in our analyses because of their rarity or inadequate preservation.

From the petrified or permineralised genera (Table 5), the Parnaíba Basin shows the highest floristic similarity with Gondwana (42.8\%), followed by Euramerica (33.3\%) and Cathaysia (23.8\%) (Fig. 4). Among the ferns, four genera are considered as endemic (Tocantinorachis, Buritiranopteris, Dernbachia, Araguainorachis), representing 50\% of endemism within the group. In terms of non-endemic ferns, Psaronius and Botryopteris are cosmopolitan; Tietea is present in the Parnaíba Basin and in the Paraná Basin (Gondwana); and Grammatopteris in the Parnaíba Basin and Euramerica, although there are close relationships to Rastropteris found in the Cathaysian province (Galtier et al., 2001). Among the gymnosperms, Carolinapitys, Cyclomedulloxylon, Teresinoxylon, Parnaiboxylon, Ductoabietoxylon and Scleroabietoxylon are endemic, representing $54.5 \%$ of endemism within the group; Amyelon is cosmopolitan; Cycadoxylon is present in the Parnaíba Basin and Euramerica, and Taeniopitys, Kaokoxylon, and Damudoxylon in the Parnaíba Basin and Gondwana. In terms of sphenophytes, both Arthropitys and Sphenophyllum are cosmopolitan, whereas single anatomical characters, such as the pitted parenchyma in the Brazilian Arthropitys species seem to be unique in this genus.

It should be emphasized that the Glossopteris-type leaves seem to be totally absent from the Permian deposits of the Parnaíba Basin (Dolianiti, 1972; Mussa and Coimbra, 1987; Rohn and Rösler, 1987), whereas not so far southward, in Altiplano of Bolivia (Iannuzzi et al., 2004) and in the Paraná Basin (Rösler, 1978; Iannuzzi and Souza, 2005; Iannuzzi, 2010), this Gondwanan key genus is present. Consequently, a major and fairly sharp phytogeographic boundary and/or transition zone south of the Parnaíba Basin is suggested, limiting the 


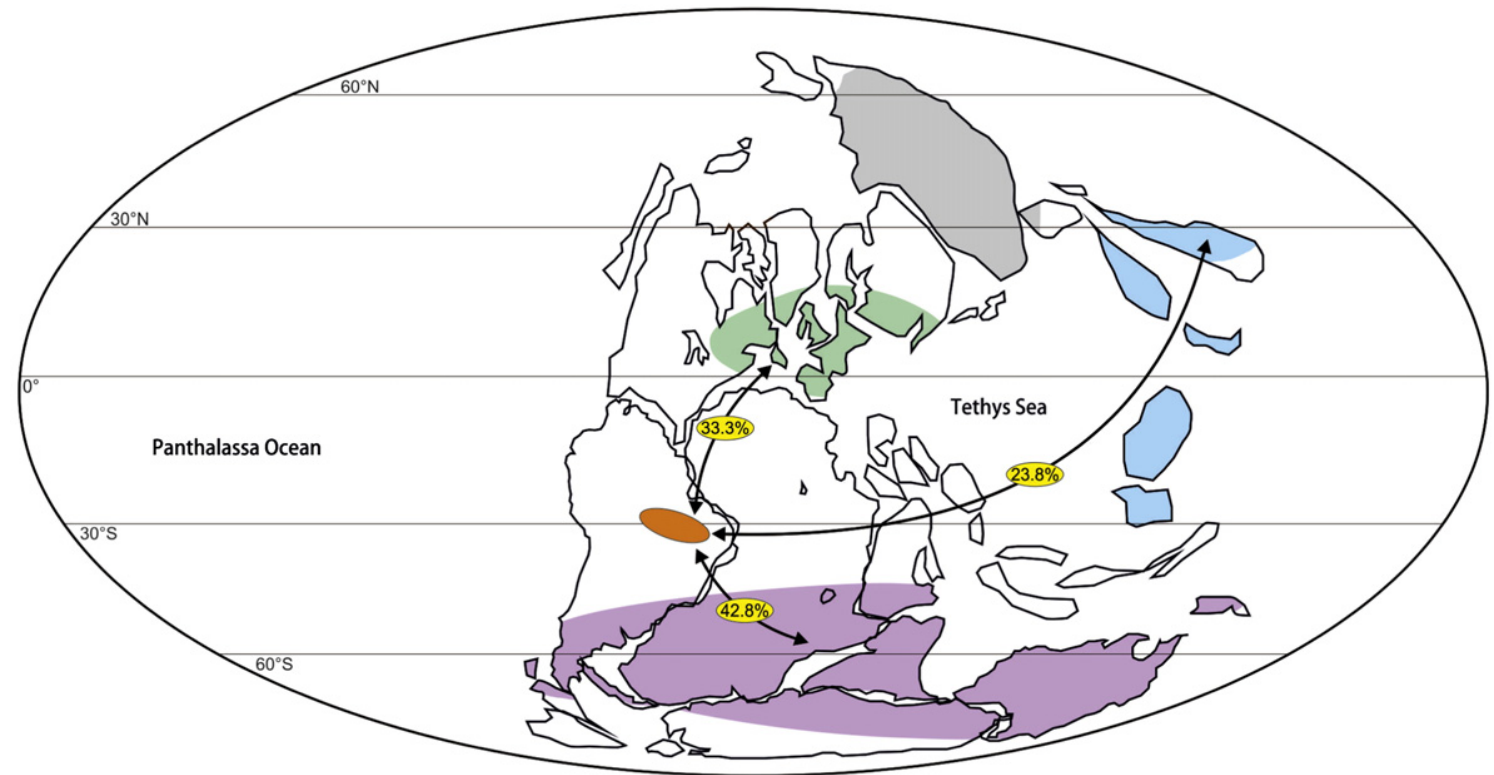

Gondwana

Euramerica

Cathaysia

Angara

Mid-North Brazilian Region

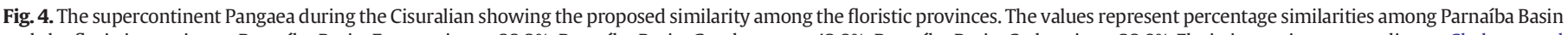

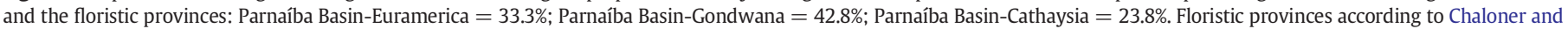
Lacey (1973), Chaloner and Meyen (1973), Meyen (1987), and Cleal and Thomas (1991). Paleogeography after Scotese (1999),

distribution northwards of some typical Gondwanan elements in South America.

The most conspicuous consequence of the taxonomic findings of recent decades is the high level of endemism observed in the Parnaíba flora. Identified taxa include 11 shared genera (Psaronius, Tietea, Grammatopteris, Botryopteris, Arthropitys, Sphenophyllum, Amyelon, Cycadoxylon, Taeniopitys, Kaokoxylon, Damudoxylon), versus 10 endemic ones (Tocantinorachis, Buritiranopteris, Dernbachia, Araguainorachis, Carolinapitys, Cyclomedulloxylon, Teresinoxylon, Parnaiboxylon, Scleroabietoxylon, Ductoabietoxylon). Applying a simple formula commonly used in modern biogeography to determine the level of endemism of a region (Cox and Moore, 2005), i.e., [number of endemic taxa $\times 100$ / total number of taxa], results in an estimate of $47.6 \%$ endemic genera for this flora (Fig. 4). This value suggests that the Parnaíba Basin flora belongs to a distinct phytogeographic unit, which could perhaps be ranked as a new Floral Region according to criteria proposed by Wnuk (1996) for the late Paleozoic.

Cluster analysis remains one of the most useful methods for biogeographical approaches (Kovach, 1988; Hammer et al., 2001). The Jaccard Coefficient is also a very powerful tool for analysing data regarding presence-absence with no importance on abundance (Legendre and Legendre, 1998; Hammer et al., 2001). Thus, cluster and Jaccard Coefficient analyses were undertaken to compare some Moscovian to Cisuralian anatomically preserved floras presented by Hilton and Cleal (2007), augmented by European floras from the Perdasdefogu Basin, Sardinia/Italy (Galtier et al., 2011), Grand-Croix, Saint-Étienne Basin, and Autun/France (Galtier, 2008), Leukersdorf Formation of the Petrified Forest of Chemnitz/Germany (Rößler, 2006), Semily and Vrchlabî formations from Krkonoše Piedmont Basin/Nova Paka/Czech Republic (data provided by Dr. Vaclav Mencl, 2015), and Irati Formation from the Paraná Basin, southern Brazil (Mussa, 1978a,b, 1982, 1986; Mussa et al., 1980; Merlotti, 2009; Merlotti and Kurzawe, 2011). Hilton and Cleal (2007) presented an analysis of 19 Euramerican and Cathaysian floras, ranging from early Bashkirian up to Asselian-Sakmarian age. Considering that the Motuca Formation is probably Cisuralian (Cisneros et al., 2015; Conceição et al., 2016a), the current analysis includes only the Moscovian and Asselian-Sakmarian floras.
The analysis has shown that the Parnaíba Basin does not have strong similarity with any other flora analysed herein (Fig. 5 and Table 6). This result reflects the fact that despite the Parnaíba flora sharing a considerable number of taxa with typical floras from the tropics and those of Gondwanan floristic province (Fig. 4; Table 5), it also reveals a high degree of endemism, both at specific and generic levels. Even when the Parnaíba Basin flora is compared to that of the Irati Formation of the Paraná Basin, the region hosting the closest fossil floras little similarity has been found.

In fact, the position of the Parnaíba Basin flora in middle latitudes, i.e., halfway between the temperate to cold regions of Gondwana and the equatorial floristic belt, well explains the results obtained from the cluster analysis. Despite all the palaeogeographic reconstructions for the Permian including the region of the Parnaíba Basin within a belt of warm climates (Rees et al., 1999, 2002; Boucot et al., 2013), none of them attributed the existence of favourable conditions for the development of tropical forests. Whether using data from climate-sensitive sediments (Boucot et al., 2013), or by using data derived from climate and vegetation model simulations (Rees et al., 1999, 2002), the region occupied by the Parnaíba Basin has always been considered as having hosted desert regimes, with arid-to-semiarid climates, during the Permian. These interpretations do not match with the extensive record of a diverse flora incorporating hygrophilous arborescent (>10 $\mathrm{m}$ high) of pteridophytes and gymnosperms (Capretz and Rohn, 2013) evident in this basin. Silica-petrified forests have been found in Permian deposits [e.g., Pedra de Fogo and Motuca formations] that are widely distributed from the southwest to northeast rims of the Parnaíba Basin, covering $>800 \mathrm{~km}$ of a narrowly outcropping fossiliferous belt. It is hard to imagine that there was no climatic variation over this vast floristic region (Rößler and Noll, 2002a,b; Capretz and Rohn, 2013; Conceição et al., 2016b).

There are several indicators in the Parnaíba floral record pointing to a seasonally dry climate regime, such as: a) the climatic-driven process of silicification (Matysová et al., 2010); b) the braided fluvial system generating the depositional settings (Capretz and Rohn, 2013); c) the occurrence of evaporites and gypsum deposits (Faria and Truckenbrodt, 1980); d) the noticeable xeromorphic features found in the fern fronds 
Table 4

Plant fossils found in the Parnaíba Basin.

\begin{tabular}{|c|c|c|c|c|}
\hline Taxon & Localities & References & Age & $\begin{array}{l}\text { Some occurrences of } \\
\text { the genera }\end{array}$ \\
\hline Psaronius brasiliensis & $\begin{array}{l}\text { Oieras/São Gonçalo do } \\
\text { Amarante (PI), } \\
\text { Araguaína/Filadélfia (TO) }\end{array}$ & $\begin{array}{c}\text { Brongniart (1872), Rößler \& } \\
\text { Noll (2002) }\end{array}$ & - & $\begin{array}{c}\text { Brazil (Paraná Basin), } \\
\text { Germany, France, USA, } \\
\text { China }\end{array}$ \\
\hline $\begin{array}{l}\text { Psaronius } \\
\text { arrojadoi }\end{array}$ & $\begin{array}{c}\text { Chapada do Jaboti (MA), } \\
\text { TFTNM }\end{array}$ & $\begin{array}{c}\text { Pelourde (1914), Herbst } \\
\text { (1985), Tavares (2011) }\end{array}$ & $\begin{array}{l}\text { Early Permian } \\
\text { (Herbst, 1985) }\end{array}$ & $\begin{array}{l}\text { Brazil (Paraná Basin), } \\
\text { Germany, France, USA, } \\
\text { China }\end{array}$ \\
\hline $\begin{array}{l}\text { Psaronius } \\
\text { sinuosus }\end{array}$ & Araguaína (TO) & $\begin{array}{l}\text { Herbst (1999), Rößler \& Noll } \\
\text { (2002) }\end{array}$ & $\begin{array}{l}\text { Early Permian } \\
\text { (Herbst, 1999) }\end{array}$ & $\begin{array}{l}\text { Brazil (Paraná Basin), } \\
\text { Germany, France, USA, } \\
\text { China }\end{array}$ \\
\hline $\begin{array}{l}\text { Tietea } \\
\text { singularis }\end{array}$ & Araguaína (TO), TFTNM & $\begin{array}{l}\text { Herbst (1986), Rößler \& Noll } \\
\text { (2002), Tavares (2011) }\end{array}$ & $\begin{array}{l}\text { Permian (Herbst, } \\
1986)\end{array}$ & Brazil (Paraná Basin) \\
\hline $\begin{array}{l}\text { Tietea } \\
\text { derbyi }\end{array}$ & Carolina (MA) & Herbst (1992) & Permian & Brazil (Paraná Basin) \\
\hline $\begin{array}{l}\text { Tocantinorachis } \\
\text { buritiranaensis }\end{array}$ & TFTNM & Tavares (2011) & Early Permian & Endemic \\
\hline Pecopteris sp. & TFTNM & Tavares (2011) & $\begin{array}{l}\text { Early-Middle } \\
\text { Permian }\end{array}$ & Cosmopolitan \\
\hline Buritiranopteris costata & TFTNM & Tavares et al. (2014) & Early Permian & Endemic \\
\hline $\begin{array}{l}\text { Grammatopteris } \\
\quad \text { freitasii }\end{array}$ & Araguaína/Filadélfia (TO) & Rößler \& Galtier (2002a) & $\begin{array}{l}\text { Permian (Rößler \& } \\
\text { Galtier, 2002a) }\end{array}$ & Germany, France \\
\hline Dernbachia brasiliensis & Araguaína/Filadélfia (TO) & Rößler \& Galtier (2002b) & $\begin{array}{l}\text { Permian (Rößler \& } \\
\text { Galtier, 2002b) }\end{array}$ & Endemic \\
\hline $\begin{array}{l}\text { Botryopteris } \\
\text { nollii }\end{array}$ & Araguaína/Filadélfia (TO) & Rößler \& Galtier (2003) & $\begin{array}{l}\text { Permian (Rößler \& } \\
\text { Galtier, 2003) }\end{array}$ & $\begin{array}{l}\text { Germany, France, } \\
\text { Belgium, USA, China }\end{array}$ \\
\hline $\begin{array}{l}\text { Araguainorachis } \\
\text { simplissima }\end{array}$ & Carolina (MA)/Riachão (TO) & Mussa \& Coimbra (1987) & $\begin{array}{l}\text { Early-Middle } \\
\text { Permian }\end{array}$ & Endemic \\
\hline $\begin{array}{l}\text { Cyclostigma } \\
\text { brasiliensis }\end{array}$ & Carolina (MA) & Iannuzzi \& Scherer (2001) & Early Permian & UK, China, Japan \\
\hline $\begin{array}{l}\text { Arthropitys } \\
\text { cacundensis }\end{array}$ & Araguaína (TO), Carolina (MA) & Coimbra \& Mussa (1984) & $\begin{array}{c}\text { Middle } \\
\text { Carboniferous- } \\
\text { Early Permian }\end{array}$ & $\begin{array}{l}\text { Germany, France, } \\
\text { England, USA, China, } \\
\text { Czech Republic }\end{array}$ \\
\hline $\begin{array}{l}\text { Arthropitys } \\
\text { isoramis }\end{array}$ & TFTNM & Neregato et al. (2015) & Early Permian & $\begin{array}{l}\text { Germany, France, } \\
\text { England, USA, China, } \\
\text { Czech Republic }\end{array}$ \\
\hline $\begin{array}{l}\text { Arthropitys } \\
\text { iannuzzii }\end{array}$ & TFTNM & Neregato et al. (2015) & Early Permian & $\begin{array}{l}\text { Germany, France, } \\
\text { England, USA, China, } \\
\text { Czech Republic }\end{array}$ \\
\hline $\begin{array}{l}\text { Arthropitys } \\
\text { tocantinensis }\end{array}$ & TFTNM & This work & Early Permian & $\begin{array}{l}\text { Germany, France, } \\
\text { England, USA, China, } \\
\text { Czech Republic }\end{array}$ \\
\hline $\begin{array}{l}\text { Arthropitys } \\
\text { barthelii }\end{array}$ & TFTNM & This work & Early Permian & $\begin{array}{l}\text { Germany, France, } \\
\text { England, USA, China, } \\
\text { Czech Republic }\end{array}$ \\
\hline Calamites sp. & Carolina (MA) & Iannuzzi \& Scherer (2001) & Early Permian & $\begin{array}{l}\text { England, Holland, } \\
\text { Germany, France, } \\
\text { Belgium, USA, China, } \\
\text { Brazil (Paraná Basin) }\end{array}$ \\
\hline Sphenophyllum sp. & Araguaína/Filadélfia (TO) & Rößler \& Noll (2002) & Permian & Cosmopolitan \\
\hline Amyelon bieloi & $\begin{array}{c}\text { Between Araguaína (TO) and } \\
\text { Carolina (MA) }\end{array}$ & Coimbra \& Mussa (1984) & $\begin{array}{c}\text { Middle } \\
\text { Carboniferous- } \\
\text { Early Permian }\end{array}$ & $\begin{array}{c}\text { England, USA, Scotland, } \\
\text { China, France }\end{array}$ \\
\hline $\begin{array}{l}\text { Carolinapitys } \\
\text { maranhensis }\end{array}$ & $\begin{array}{c}\text { Between Araguaína (TO) and } \\
\text { Carolina (MA) }\end{array}$ & Coimbra \& Mussa (1984) & $\begin{array}{c}\text { Middle } \\
\text { Carboniferous- } \\
\text { Early Permian }\end{array}$ & Endemic \\
\hline $\begin{array}{l}\text { Cyclomedulloxylon } \\
\text { parnaibense }\end{array}$ & Carolina (MA)/Riachão (TO) & Mussa \& Coimbra (1987) & $\begin{array}{l}\text { Early-Middle } \\
\text { Permian }\end{array}$ & Endemic \\
\hline $\begin{array}{c}\text { Cycadoxylon } \\
\text { brasiliense }\end{array}$ & Carolina/Riachão (TO) & Mussa \& Coimbra (1987) & $\begin{array}{l}\text { Early-Middle } \\
\text { Permian }\end{array}$ & France, England \\
\hline
\end{tabular}


Table 4 (continued)

\begin{tabular}{|c|c|c|c|c|}
\hline Teresinoxylon euzebioi & Teresina (PI) & Caldas et al. (1989) & $\begin{array}{l}\text { Early-Middle } \\
\text { Permian }\end{array}$ & Endemic \\
\hline Parnaiboxylon sp. & TFTNM & Kurzawe et al. (2013a) & Permian & Endemic \\
\hline $\begin{array}{l}\text { Parnaiboxylon } \\
\text { rohnae }\end{array}$ & TFTNM & Kurzawe et al. (2013a) & Permian & Endemic \\
\hline $\begin{array}{c}\text { Scleroabietoxylon } \\
\text { chordas }\end{array}$ & TFTNM & Kurzawe et al. (2013a) & Permian & Endemic \\
\hline $\begin{array}{l}\text { Ductoabietoxylon } \\
\text { solis }\end{array}$ & TFTNM & Kurzawe et al. (2013a) & Permian & Endemic \\
\hline $\begin{array}{l}\text { Taeniopitys } \\
\text { tocantinensis }\end{array}$ & TFTNM & Kurzawe et al. (2013b) & Permian & Antarctica \\
\hline Taeniopitys sp. & TFTNM & Kurzawe et al. (2013b) & Permian & Antarctica \\
\hline $\begin{array}{l}\text { Kaokoxylon } \\
\text { punctatum }\end{array}$ & TFTNM & Kurzawe et al. (2013b) & Permian & $\begin{array}{c}\text { India, Australia, South } \\
\text { Africa, Argentina, } \\
\text { Antarctica }\end{array}$ \\
\hline $\begin{array}{l}\text { Damudoxylon } \\
\text { buritiranaensis }\end{array}$ & TFTNM & Kurzawe et al. (2013b) & Permian & $\begin{array}{c}\text { India, Australia, South } \\
\text { Africa }\end{array}$ \\
\hline $\begin{array}{l}\text { Damudoxylon } \\
\text { humile }\end{array}$ & TFTNM & Kurzawe et al. (2013b) & Permian & $\begin{array}{c}\text { India, Australia, South } \\
\text { Africa }\end{array}$ \\
\hline $\begin{array}{l}\text { Damudoxylon } \\
\text { roesslerii }\end{array}$ & TFTNM & Kurzawe et al. (2013b) & Permian & $\begin{array}{c}\text { India, Australia, South } \\
\text { Africa }\end{array}$ \\
\hline $\begin{array}{l}\text { Rhachiphyllum } \\
\text { schenkii }\end{array}$ & Nova Iorque (MA) & Iannuzzi \& Langer (2013) & $\begin{array}{c}\text { Late } \\
\text { Carboniferous- } \\
\text { Early Permian }\end{array}$ & $\begin{array}{l}\text { USA, north Africa, } \\
\text { Germany, France, } \\
\text { Russia, China, Malay, } \\
\text { southeast Asia }\end{array}$ \\
\hline
\end{tabular}

TO = Tocantins State, MA = Maranhão State, PI = Piauí State, TFTNM = Tocantins Fossil Trees Natural Monument. In the left column, green representing ferns, yellow lycophytes, pink sphenophytes, and blue gymnosperms.

of Buritiranopteris costata (Tavares et al., 2014); e) the growth-ring-like patterns found in Arthropitys stems (Neregato et al., 2015), roots (Rößler et al., 2014), and in associated gymnosperms (Kurzawe et al., 2013a, 2013b; Benício et al., 2015). However, availability of water must have existed annually to support the diversity of plant groups and their arborescent stature. The majority of trees may have grown over several years to reach such dimensions, both in diameter and in height. Based on all these considerations, the modern biome that best equates with the floral register from the Parnaíba Basin is that of "Tropical summerwet" following the climate modelling established by Rees et al. (2002).

Therefore, instead of being understood as a transitional floristic belt, the Parnaíba Basin should be considered a unique region occupied by a flora constituting its own phytogeographic unit. The palaeogeographic (approx. $30^{\circ}$ south), climatic (tropical warm semiarid) and sedimentary (braided fluvial system) data support this conclusion, indicating a set of biotic and abiotic features exclusive to this region, which explains the development of a diverse flora adapted to these unique conditions. Therefore, we propose formally a new phytogeographic unit named herein as the "Mid-North Brazilian Region" based on the Parnaíba flora, representing the record of tropical summerwet climate that existed in the southern mid-latitudes of northern Gondwana during the Cisuralian (Fig. 5). Unfortunately, any equivalent early Permian anatomically preserved floras are known in north-western South America or in central-north Africa that could be attributed to this province until now. Nonetheless, this new unit fits quite well with previous records describing the occurrence of so-called "Tropical Gondwana", a belt having Euroamerican adpressed floras that was distributed by the north rim of West Gondwana, including the northwestern of South America (e.g., Venezuela; Ricardi-Branco, 2008) and northern Africa (Chaloner and Meyen, 1973; Lejal-Nicol, 1985; Doubinger and Roy-Dias, 1985).
Table 5

Petrified or permineralised genera occurring in the Parnaíba Basin and in Gondwana, Euramerica, and Cathaysia.

\begin{tabular}{|l|c|c|c|c|}
\hline & $\begin{array}{c}\text { Parnaíba } \\
\text { Basin }\end{array}$ & Euramerica & Gondwana & Cathaysia \\
\hline Psaronius & $\mathrm{x}$ & $\mathrm{x}$ & $\mathrm{x}$ & $\mathrm{x}$ \\
\hline Tietea & $\mathrm{x}$ & - & $\mathrm{x}$ & - \\
\hline Tocantinorachis & $\mathrm{x}$ & - & - & - \\
\hline Buritiranopteris & $\mathrm{x}$ & - & - & - \\
\hline Grammatopteris & $\mathrm{x}$ & $\mathrm{x}$ & - & - \\
\hline Dernbachia & $\mathrm{x}$ & - & - & - \\
\hline Botryopteris & $\mathrm{x}$ & $\mathrm{x}$ & $\mathrm{x}$ & $\mathrm{x}$ \\
\hline Araguainorachis & $\mathrm{x}$ & - & - & - \\
\hline Arthropitys & $\mathrm{x}$ & $\mathrm{x}$ & $\mathrm{x}$ & $\mathrm{x}$ \\
\hline Sphenophyllum & $\mathrm{x}$ & $\mathrm{x}$ & $\mathrm{x}$ & $\mathrm{x}$ \\
\hline Amyelon & $\mathrm{x}$ & $\mathrm{x}$ & $\mathrm{x}$ & $\mathrm{x}$ \\
\hline Carolinapitys & $\mathrm{x}$ & - & - & - \\
\hline Cyclomedulloxylon & $\mathrm{x}$ & - & - & - \\
\hline Cycadoxylon & $\mathrm{x}$ & $\mathrm{x}$ & - & - \\
\hline Teresinoxylon & $\mathrm{x}$ & - & - & - \\
\hline Parnaiboxylon & $\mathrm{x}$ & - & - & - \\
\hline Scleroabietoxylon & $\mathrm{x}$ & - & - & - \\
\hline Ductoabietoxylon & $\mathrm{x}$ & - & - & - \\
\hline Taeniopitys & $\mathrm{x}$ & - & $\mathrm{x}$ & - \\
\hline Kaokoxylon & $\mathrm{x}$ & - & $\mathrm{x}$ & - \\
\hline Damudoxylon & $\mathrm{x}$ & - & $\mathrm{x}$ & - \\
\hline References & $\mathrm{xan}$ Pathe & - & & \\
\hline
\end{tabular}

References in the Parnaíba Basin: Psaronius: Pelourde (1914), Brongniart (1872). Herbst (1985, 1999), Rößler and Noll (2002), Tavares (2011); Tietea: Herbst (1986, 1992), Rößler and Noll (2002), Tavares (2011); Pecopteris: Tavares (2011); Grammatopteris: Rößler and Galtier (2002a); Botryopteris: Rößler and Galtier (2003); Arthropitys: Coimbra and Mussa (1984), Rößler and Noll (2002), Neregato et al. (2015); Sphenophyllum: Rößler and Noll (2002); Amyelon: Coimbra and Mussa (1984); Cycadoxylon: Mussa and Coimbra (1987); Taeniopitys: Kurzawe et al. (2013b); Kaokoxylon: Kurzawe et al. (2013b); Damudoxylon: Kurzawe et al. (2013b); In the left column, green representing ferns, pink sphenophytes, and blue gymnosperms. 


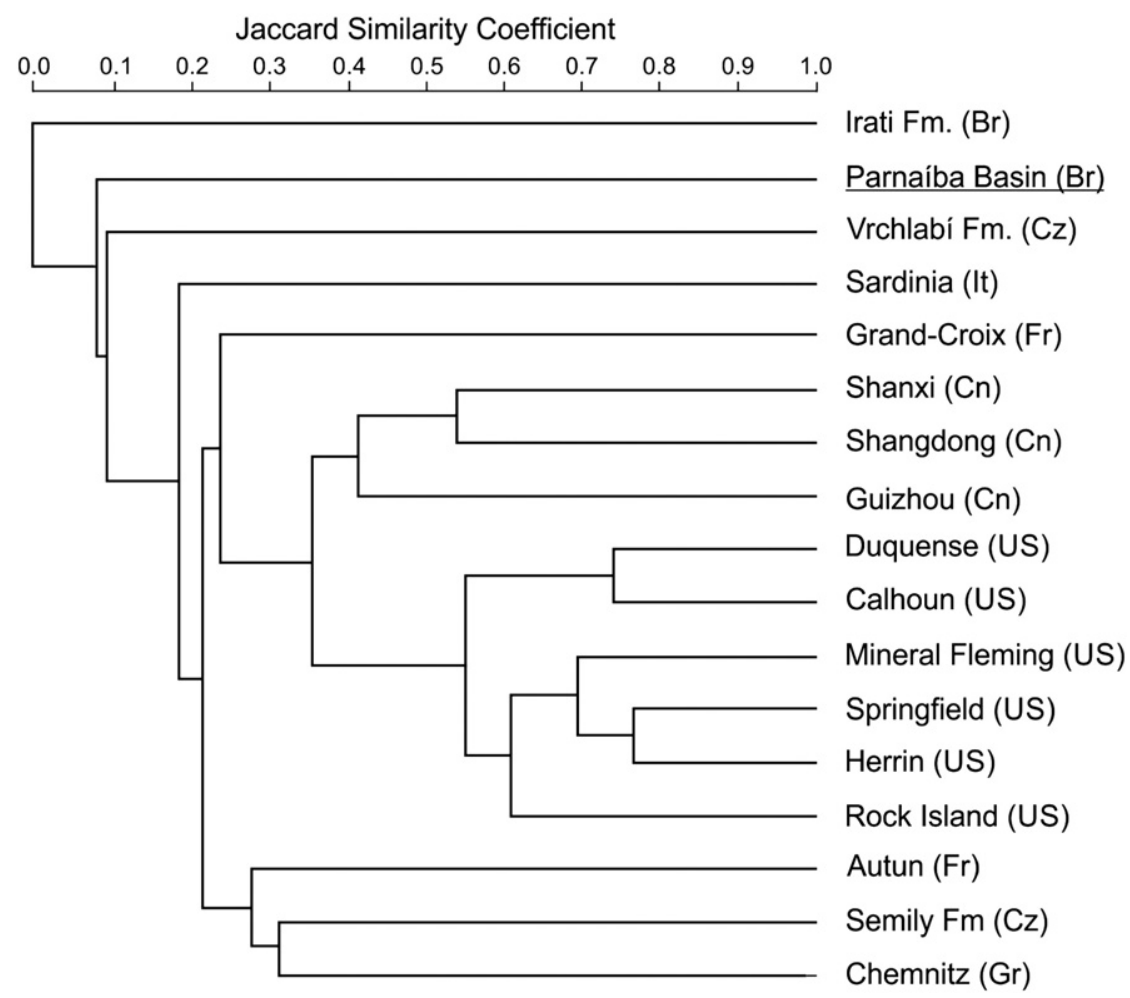

Fig. 5. Cluster analysis among late Carboniferous - Cisuralian floras and those of the Parnaíba Basin. The data used in this analysis are shown in the Supplementary data.

Lastly, it is worth mentioning that perhaps the discrepancy observed by the presence of this flora in the Mid-North Brazilian Region with that expected from the climate model represents an aberration caused by the occurrence of large inland water bodies widely distributed and interconnected in the northeast of the South American continent, which might have provided higher moisture levels on the lowlands of this region. Unfortunately, the effects of the presence of epeiric seas on regional climates have not been adequately accounted for in the palaeogeographic reconstructions or climate modelling, but their consequences should be considered.

\section{Conclusions}

1) Present investigations reveal much more anatomical and growth form diversity among low-latitude Permian calamitaleans of Gondwana. Although of overall similarity and easily recognisable at generic level, there are several anatomical or branching characteristics enabling segregation of these arborescent pteridophytes at species level.

2) Based on their anatomical and branching characteristics two new species, Arthropitys tocantinensis sp. nov. and Arthropitys barthelii sp. nov., are introduced. Both species share the peculiar pitting of parenchyma with the recently described species Arthropitys isoramis and Arthropitys iannuzzii.

3) Although sharing similar systems of stem or branch construction and secondary adventitious roots, these Permian calamitaleans have considerable plasticity in the morphological and anatomical development of all plant organs.

4) Stems, branches and roots are parenchyma-rich organs, which can show considerable secondary growth. Like an archive of environmental fluctuations the resulting wood regularly exhibits growthring-like tissue density variations reflecting seasonal changes in the palaeoenvironment.

Table 6

Jaccard Coefficient among Parnaíba Basin flora with some Moscovian to Cisuralian floras around the world.

\begin{tabular}{|c|c|c|}
\hline Locality & Age (Ma) & $\begin{array}{l}\text { Jaccard coefficient among Late Carboniferous - } \\
\text { Cisuralian floras and Parnaíba Basin }\end{array}$ \\
\hline Vrchlabí Fm (Cz) & 298.9-295.0 (Martínek and Štolfova, 2009) & 0.041667 \\
\hline Irati $\mathrm{Fm}(\mathrm{Br})$ & $278.4 \pm 2.2($ Santos et al., 2006) & 0.046512 \\
\hline Springfield (US) & $315.2-307.0$ (Hilton and Cleal, 2007) & 0.055556 \\
\hline Herrin (US) & 315.2-307.0 (Hilton and Cleal, 2007) & 0.056604 \\
\hline Grand-Croix (Fr) & 307.0-298.9 (Galtier, 2008) & 0.060241 \\
\hline Mineral-Flemming (US) & 315.2-307.0 (Hilton and Cleal, 2007) & 0.075472 \\
\hline Calhoun (US) & 307.0-298.9 (Hilton and Cleal, 2007) & 0.078431 \\
\hline Shangdong (Cn) & 298.9-290.1 (Hilton and Cleal, 2007) & 0.083333 \\
\hline Shanxi $(\mathrm{Cn})$ & 298.9-290.1 (Hilton and Cleal, 2007) & 0.085106 \\
\hline Rock Island (US) & 315.2-307.0 (Hilton and Cleal, 2007) & 0.086957 \\
\hline Duquense (US) & 307.0-298.9 (Hilton and Cleal, 2007) & 0.086957 \\
\hline Semily Fm. (Cz) & 303-7-301(Martínek and Štolfova, 2009) & 0.096774 \\
\hline Sardinia (It) & 298.9-290.1 (Galtier et al., 2011) & 0.1 \\
\hline Autumn (Fr) & 298.9-272.3 (Galtier, 2008) & 0.102041 \\
\hline Chemnitz (Gr) & $290.6 \pm 1.8$ (Rößler et al., 2012) & 0.108108 \\
\hline Guizhou (Cn) & - & 0.125 \\
\hline
\end{tabular}

Data used in this analysis are shown in the Supplementary data. 
5) We report the striking intergrowth of Arthropitys barthelii sp. nov. with Sphenophyllum, up to 30 axes of the latter showing different ontogenetic stages and growing inside the calamite's pith that was previously excavated by arthropod boring.

6) Based on a set of biotic and abiotic features exclusive to the Parnaíba Basin, a new palaeophytogeographic province is formally proposed herein as the "Mid-North Brazilian Region" representing a diverse flora adapted to a tropical summerwet climate that existed in the southern low- to mid-latitudes of northern Gondwana during the Cisuralian.

\section{Acknowledgements}

We would like to thank the Brazilian Research Council ("Conselho Nacional de Desenvolvimento Científico e Tecnológico" - CNPq) for the PhD scholarship (Process 141365/2008-0) to the first author (RN), for financial support to the project in the Parnaíba Basin (Process 483704/2010-5), and grants (PQ 305687/2010-7 and PQ 309211/ 2013-1) to Roberto Iannuzzi. Acknowledgements are also due to the Deutsche Forschungsgemeinschaft (DFG grant RO 1273/3-1 to R.R.). We are indebted to Dr. Václav Mencl, Nová Paka, for providing palaeofloristic data from the Krkonoše Piedmont Basin. Dr. Jason Hilton (University of Birmingham) and Dr. Christopher Cleal (National Museum Wales, Cardiff) kindly provide the data used in the cluster analysis. Dr. Jean Galtier (Montpelier) is acknowledged for valuable comments concerning anatomical features and Ludwig Luthardt (Chemnitz) kindly shared his knowledge on climate-induced wood growth. Finally, this manuscript greatly benefited from the detailed helpful suggestions provided by two anonymous reviewers and the editor, Hans Kerp.

\section{Appendix A. Supplementary data}

Supplementary data to this article can be found online at http://dx. doi.org/10.1016/j.revpalbo.2016.11.001.

\section{References}

Anderson, B.R., 1954. A study of American petrified calamites. Ann. Mo. Bot. Gard. 41, 395-418.

Andrews, H.N., 1952. Some American petrified calamitean stems. Ann. Mo. Bot. Gard. 39, 189-206.

Barthel, M., 2004. Die Rotliegendflora des Thüringer Waldes. Teil 2: Calamiten und Lepidophyten. Veröffentlichungen des Naturhistorischen Museums Schleusingen $19,19-48$.

Benício, J.R.W., Spiekermann, R., Manfroi, J., Uhl, D., Pires, E.F., Jasper, A., 2015. Paleoclimatic inferences based on dendrological patterns of permineralized wood from the Permian of the northern Tocantins Petrified Forest, Parnaíba Basin, Brazil. Paleobio. Paleoenv http://dx.doi.org/10.1007/s12549-015-0218-8.

Blakey, R.C., 2008. Gondwana paleogeography from assembly to breakup - a 500 m.y. odyssey. Geol. Soc. Am. Spec. Pap. 441, 1-28

Boucot, A.J., Xu, C., Scotese, C.R., Morley, R.J., 2013. Phanerozoic Paleoclimate: an atlas of lithologic indicators of climate. SEPM Concepts in Sedimentology and Paleontology 11. Folio, p. 478

Brongniart, A., 1872. Notice sur le Psaronius brasiliensis. Bull. Soc. Bot. France, Ser. 5 (19), $3-10$

Capretz, R.L., Rohn, R., 2013. Lower Permian stems as fluvial paleocurrent indicators of the Parnaíba Basin, northern Brazil. J. S. Am. Earth Sci. 45, 69-82.

Chaloner, W.G. Lacey, W.S., 1973. The distribution of Late Paleozoic Flora. In: Hughes, N.F. (Ed.), Organisms and Continents Through Time. Methods for Assessing Relationships Between Past and Present Biologic Distribution and the Position of ContinentsSpec Pap. Palaeontol 12. Palaeontological Association, London, pp. 271-289.

Chaloner, W.G., Meyen, S.V., 1973. Carboniferous and permian floras of the northern continents. In: Hallan, A. (Ed.), Atlas of Paleobiogeography. Elsevier, Amsterdam, pp. 169-186.

Chumakov, N.M., Zharkov, M.A., 2002. Climate during Permian-Triassic biosphere reorganizations, article 1: climate of the early Permian. Stratigr. Geol. Correl. 10, 586-602.

Cichan, M.A., Taylor, T.N., 1983. A systematic and developmental analysis of Arthropitys deltoides sp. nov. Bot. Gaz. 144, 285-294.

Cisneros, J.C., Marsicano, C., Angielczyk, K.D., Smith, R.M.H., Richter, M., Fröbisch, J., Kammerer, C.F., Sadleir, R.W., 2015. New Permian fauna from tropical Gondwana. Nat. Commun. 6, 8676.

Cleal, C.J., Thomas, B.A., 1991. Carboniferous and Permian palaeogeography. In: Cleal, C.J. (Ed.), Plant Fossils in Geological Investigation: The Paleozoic. Ellis Horwood Ltd., England, pp. 155-181.

Cleal, C.J., Thomas, B.A., 1994. Plant Fossils of the British Coal Measures. Palaeontologica Association, London (222 pp).
Coimbra, A.M., Mussa, D, 1984. Associação lignitafoflorística na Formação Pedra-de-Fogo, (Arenito Cacunda), Bacia do Maranhão - Piauí, Brasil. XXXIII Congresso Brasileiro de Geologia. Sociedade Brasileira de Geologia, Rio do Janeiro, pp. 591-605.

Conceição, D.M., Andrade, L.S., Cisneros, J.C., Iannuzzi, R., Pereira, A.A., Machado, F.C., 2016a. New petrified forest in Maranhão, Permian (Cisuralian) of the Parnaíba Basin, Brazil. J. S. Am. Earth Sci. 70, 308-323.

Conceição, D.M., Cisneros, J.C., Iannuzzi, R., 2016b. Novo registro de uma Floresta Petrificada em Altos, Piauí: relevância e estratégias para geoconservação. Pesquisas em Geociências 43, 311-324.

Cox, C.B., Moore, P.D., 2005. Biogeography: An Ecological and Evolutionary Approach. seventh ed. Blackwell Publishing, Oxford (440 pp).

Dawson, J.W., 1851. Notice on the occurrence of upright Calamites near Pictou, Nova Scotia. Quarterly J. Geological Soc. London 7, 194-196.

Dernbach, U., Roll, R., Rößler, R., 2002. News from Araguaina, Brazil. In: Dernbach, U., Tidwell, W.D.I. (Eds.), Secrets of Petrified Plants - Fascination From Millions of Years. D'Oro-Verlag, Heppenheim, pp. 78-87.

Dias-Brito, D., Rohn, R., Castro, J.C., Dias, R.R., Rössler, R., 2007. Floresta Petrificada do Tocantins Setentrional - $O$ mais exuberante e importante registro florístico tropicalsubtropical permiano no Hemisfério Sul. In: Winge, M., Schobbenhaus, C., BerbertBorn, M., Queiroz, E.T., Campos, D.A., Souza, C.R.G., Fernandes, A.C.S. (Eds.), Sítios Geológicos e Paleontológicos do Brasil. DNPM/CPRM-SIGEP, Brasília. Available online 23/01/2007 at: http://www.unb.br/ig/sigep/sitio104/sitio104english.pdf, (14 pp).

Dickins, J.M., 1993. Climate of the Late Devonian to Triassic. Palaeogeogr. Palaeoclimatol. Palaeoecol. 100, 89-94.

DiMichele, W.A., Aronson, R.B., 1992. The Pennsylvanian-Permian vegetation transition: a terrestrial analogue to the onshore-offshore hypothesis. Evolution 46, 807-824.

DiMichele, W.A., Falcon-Lang, H.J., 2011. Fossil forests in growth position ( $\mathrm{T}^{0}$ assemblages): origin, taphonomic biases and palaeoecological significance. J. Geol. Soc. $168,585-605$.

DiMichele, W.A., Falcon-Lang, H.J., 2012. Calamitalean pith casts reconsidered. Rev. Palaeobot. Palynol. 173, 1-14.

DiMichele, W.A., Kerp, H., Tabor, N.J., Looy, C.V., 2008. The so-called "Paleophytic-Mesophytic" transition in equatorial Pangea - multiple biomes and vegetational tracking of climate change through geological time. Palaeogeogr. Palaeoclimatol. Palaeoecol. 268, 152-163.

Dolianiti, E., 1972. Relações entre as floras paleozóicas do Brasil. An. Acad. Bras. Cienc. 44, $113-118$.

Doubinger, J., Roy-Dias, C., 1985. La paléoflore du Stéphanien de l'Qued Zat (Haut-Atlas de Marrakech, versant nord, Marroc). Geobios 18, 575-594.

Falcon-Lang, H.J., 2015. A calamitalean forest preserved in growth position in the Pennsylvanian coal measures of South Wales: implications for paleoecology, ontogeny and taphonomy. Rev. Palaeobot. Palynol. 214, 51-67.

Faria Jr., L.E.C., Truckenbrodt, W., 1980. Estratigrafia e petrografia da Formação Pedra de Fogo - Permiano da Bacia do Parnaíba. XXXI Congresso Brasileiro de Geologia 2. Sociedade Brasileira de Geologia, Camboriú, pp. 740-754

Feng, Z., Zierold, T., Rößler, R., 2012. When horsetails became giants. Chin. Sci. Bull. 57. $2285-2288$

Fluteau, F., Besse, J., Broutin, J., Ramstein, G., 2001. The Late Permian climate. What can be inferred from climate modeling concerning Pangaea scenarios and Hercynian range altitude? Palaeogeogr. Palaeoclimatol. Palaeoecol. 167, 39-71.

Galtier, J., 1997. Coal-ball floras of the Namurian-Westphalian of Europe. Rev. Palaeobot. Palynol. 95, 51-72.

Galtier, J., 2008. A new look at the permineralized flora of Grand-Croix (Late Pennsylvanian, Saint-Etienne basin, France). Rev. Palaeobot. Palynol. 152, 129-140.

Galtier, J., Wang, S.J., Li, C.S., Hilton, J., 2001. A new genus of filicalean fern from the Lower Permian of China. Bot. J. Linn. Soc. London 147, 429-442.

Galtier, J., Ronchi, A., Broutin, J., 2011. Early Permian silicified floras from the Perdasdefogu Basin (SE Sardinia): comparison and bio-chronostratigraphic correlation with the floras of the Autun Basin (Massif Central, France). Geodiversitas 33, 43-69.

Gastaldo, R.A. 1992. Regenerative growth in fossil horsetails (Calamites) following burial by alluvium. Hist. Biol. 6, 203-220.

Goeppert, H.R., 1864-1865. Die fossile Flora der Permischen formation. Palaeontographica $12,1-124$

Góes, A.M.O., Feijó, F.J., 1994. Bacia do Parnaíba. Boletim de Geociências da Petrobrás 8, 57-67.

Grand'Eury, C.F., 1877. Mémoire sur la flore Carbonifère du département de La Loire et du centre de la France. Mém. Acad. Sci. Inst. Nat. Fr. 24 (624 pp).

Hammer, Ø., Harper, D.A.T., Ryan, P.D. 2001. PAST: Paleontological statistics software package for education and data analysis. Available at: http://paleo-electronica.org/ 2001_1/past/issue1_01.htm.

Haq, B.U., Schutter, S.R., 2008. A chronology of Paleozoic sea-level changes. Science 322, 64-68.

Herbst, R., 1985. Nueva descripcion de Psaronius arrojadoi (Pelourde) (Marattiales), del Permico de Brasil. Ameghiniana 21, 243-258.

Herbst, R., 1986. Studies on Psaroniaceae. I. The family Psaroniaceae (Marattiales) and a Redescription of Tietea singularis Solms-Laubach, From the Permian of Brazil. IV Congresso Argentino de Paleontologia y Bioestratigrafia. Asociación Paleontológica Argentina, Mendoza, pp. 163-171.

Herbst, R., 1992. Studies on Psaroniaceae. III. Tietea derbyi n. sp., from the Permian of Brazil. Cour. Forschungsinst. Senckenb. 147, 155-161.

Herbst, R., 1999. Studies on Psaroniaceae. IV. Two species of Psaronius from Araguaína, state of Tocantins, Brazil. Facena 15, 9-18.

Hilton, J., Cleal, C.J., 2007. The relationship between Euramerican and Cathaysian tropical floras in the Late Palaeozoic: Palaeobiogeographical and palaeogeographical implications. Earth-Sci. Rev. 85, 85-116. 
Iannuzzi, R., 2010. The flora of early Permian coal measures from the Paraná Basin in Brazil: a review. Int. J. Coal Geol. 83, 229-247.

Iannuzzi, R., Langer, M.C., 2014. The presence of callipterids in the Permian of northeastern Brazil: stratigraphic and phytogeographical implications. In: Rocha, R., Pais, J., Kullberg, J.C., Finney, S. (Eds.), STRATI 2013: First International Congress on Stratigraphy. Springer Geology, Cham, pp. 403-406.

Iannuzzi, R., Scherer, C.M.S., 2001. Vegetais fósseis carbonificados na Formação Pedra-deFogo, Bacia do Paranaíba, TO-MA: significado paleoambiental. II Simpósio sobre a Bacia do Araripe e bacias interiores do Nordeste, Crato, 1997. Sociedade Brasileira de Paleontologia, Fortaleza, pp. 129-139.

Iannuzzi, R., Souza, P.A., 2005. Floral succession in the Lower Permian deposits of the Brazilian Paraná Basin: an up-to-date overview. Bull. New Mexico Museum Natural History and Science $30,144-149$.

Iannuzzi, R., Vieira, C.E.L., Sommer, M.G., Díaz-Martínez, E., Grader, G.W., 2004. Permian plants from the Chutani formation (Titicaca Group, northern Altiplano of Bolivia): II. The morphogenus Glossopteris. An. Acad. Bras. Cienc. 76, 129-138.

Jones, B., Renaut, R.W., Rosen, M.R., Klyen, L., 1998. Primary siliceous rhizoliths from loop road Hot Springs, North Island, New Zealand. J. Sediment. Res. 68, 115-123.

Josten, K.-H., 1991. Die Steinkohlen-Floren Nordwestdeutschlands. Fortschritte Geologie Rheinland und Westfalen. 36 (434 pp).

Kovach, W.L., 1988. Multivariate methods of analyzing paleoecological data. In: DiMichele, W.A., Wing, S.L. (Eds.), Methods and Applications of Plant Paleoecology. The Paleontological Society Spec. Publ. 3, pp. 72-104 (Tennessee).

Kurzawe, F., Iannuzzi, R., Merlotti, S., Rößler, R., Noll, R., 2013a. New gymnospermous woods from the Permian of the Parnaíba Basin, northeastern Brazil, part I: Ductoabietoxylon, Scleroabietoxylon and Parnaiboxylon. Rev. Palaeobot. Palynol. 195, 37-49.

Kurzawe, F., Iannuzzi, R., Merlotti, S., Rohn, R., 2013b. New gymnospermous woods from the Permian of the Parnaíba Basin, northeastern Brazil, part II: Damudoxylon, Kaokoxylon and Taeniopitys. Rev. Palaeobot. Palynol. 195, 50-64.

Legendre, P., Legendre, L., 1998. Numerical Ecology. second ed. Elsevier, Amsterdam (853 pp.).

Lejal-Nicol, A., 1985. Carboniferous megafloras of North Africa. In: Martinez-Diaz, C. (Ed.), The Carboniferous of the World. I.G.M.E., Madrid, Tomo. vol. II, pp. 386-391.

Löcse, E., Meyer, J., Klein, R., Linnemann, U., Weber, J., Rößler, R., 2013. Neue Florenfunde in einem Vulkanit des Oberkarbons von Flöha. Veröffentlichungen des Museums für Naturkunde Chemnitz 36, 85-142.

Luthardt, L., Rößler, R., Schneider, J.W., 2015. Palaeoclimatic and site-specific conditions in the early Permian fossil forest of Chemnitz - Sedimentological, geochemical and palaeobotanical evidence. Palaeogeogr. Palaeoclimatol. Palaeoecol. 441, 627-652.

Martínek, K., Štolfova, K., 2009. Provenance study of Permian non-marine sandstones and conglomerates of the Krkonoše Piedmont Basin (Czech Republic): exotic marine limestone pebbles, heavy minerals and garnet composition. Bull. Geosci. 84, 1-14.

Matysová, P., Rößler, R., Götze, J., Leichmann, J., Forbes, G., Taylor, E.L., Sakala, J., Grygar, T., 2010. Alluvial and volcanic pathways to silicified plant stems (Upper CarboniferousTriassic) and their taphonomic and environmental meaning. Palaeogeogr. Palaeoclimatol. Palaeoecol. 292, 127-143.

Merlotti, S., 2009. Reavaliação taxonômica de lenhos das formações Irati e Serra Alta, Permiano da Bacia do Paraná, Brasil. Pesquisas em Geociências 36, 11-21.

Merlotti, S., Kurzawe, F., 2011. Lenhos permianos da Bacia do Paraná, Brasil: síntese e revisão taxonômica. Gaea 7, 19-33.

Meyen, S.V., 1987. Fundamentals of Palaeobotany. Chapman \& Hall Ltd, London (432 pp).

Montañez, I.P., Poulsen, C.J., 2013. The Late Paleozoic ice age: an evolving paradigm. Annu. Rev. Earth Planet. Sci. 41, 629-656.

Mussa, D., 1978a. Brasilentiloxylon e Solenobrasilioxylon, dois novos gêneros gondwânicos na Formação Irati, Estado de São Paulo. Boletim IG-USP 9, 118-127.

Mussa, D., 1978b. On the anatomy of wood showing affinities with the genus Vertebraria Royle, from the Irati formation, state of São Paulo, Brazil. Boletim IG-USP 9, 153-201.

Mussa, D., 1982. Lignitafofloras permianas da Bacia do Paraná (Estados de São Paulo e Santa Catarina). (Ph.D. Thesis). vol. 1. Instituto de Geociências - Universidade de São Paulo, São Paulo (463 pp).

Mussa, D., 1986. Eustelos gondwânicos de medulas diafragmadas e sua distribuição estratigráfica. Boletim IG-USP 17, 11-26.

Mussa, D., Coimbra, A.M., 1984. Método de estudo tafonômico aplicado a lignispécimes permianos da Bacia do Paraná. An. Acad. Bras. Cienc. 56, 85-101.

Mussa, D., Coimbra, A.M., 1987. Novas perspectivas de comparação entre as tafofloras permiannas (de lenhos) das bacias do Parnaíba e do Paraná. X Congresso Brasileiro de Paleontologia. Sociedade Brasileira de Paleontologia, Rio de Janeiro, pp. 901-923.

Mussa, D., Carvalho, R.G., Santos, P.R., 1980. Estudo estratigráfico e paleoecológico em ocorrências fossilíferas da Formação Irati, Estado de São Paulo, Brasil. Boletim IGUSP $11,142-149$.

Neregato, R., 2012. Esfenófitas do Monumento Natural das Árvores Fossilizadas do Tocantins, Bacia do Parnaíba (Permiano, Brasil). (Ph.D. Thesis). Instituto de Geociências e Ciências Exatas - Universidade Estadual Paulista "Júlio de Mesquita Filho", Rio Claro (189 pp).

Neregato, R., RößLer, R., Rohn, R., Noll, R., 2015. New petrified calamitaleans from the Permian of the Parnaíba Basin, central-north Brazil. Part I. Rev. Palaeobot. Palynol. 215, 23-45.

Noll, R., 2000. Ein zierlicher Calamit vom Donnersberg. Veröffentlichungen des Naturhistorischen Museums Schleusingen 24, 51-58.

Opluštil, S., Pšenika, J., Libertín, M., Bek, J., Daškova, J., Šimunek, Z., Drabkova, J., 2009. Composition and structure of an in situ Middle Pennsylvanian peat-forming plant assemblage buried in volcanic ash, Radnice Basin (Czech Republic). PALAIOS 24, $726-746$.

Parrish, J.T., 1995. Geologic evidence of Permian climate. In: Scholle, P.A., Peryt, T.M., Ulmer-Scholle, D.S. (Eds.), The Permian of the Northern PangeaPaleogeography, Paleoclimates, Stratigraphy 1. Springer Verlag, Berlin, pp. 53-61.
Pelourde, F., 1914. A propos dês Psaroniées du Brésil. Association Française pour l'avancement des Sciences. Compte-rendu de la 43me session Le Havre (442-445 pp).

Petzholdt, A., 1841. Ueber Calamiten und Steinkohlenbildung. Arnoldische Buchhandlung Dresden and Leipzig (68 pp).

Pfefferkorn, H.W., Archer, A.W., Zodrow, E.L., 2001. Modern tropical analogs for standing carboniferous forests: comparison of extinct Mesocalamites with extant Montrichardia. Hist. Biol. 15, 235-250.

Pinto, C.P., Sad, J.H.G., 1986. Revisão da estratigrafia da Formação Pedra de Fogo, borda sudoeste da Bacia do Parnaíba. XXXIV Congresso Brasileiro de Geologia. Sociedade Brasileira de Geologia, Goiânia, pp. 346-358.

Rees, P.M., Gibbs, M.T., Ziegler, A.M., Kutzbach, J.E., Behling, P.J., 1999. Permian climates: evaluating model predictions using global paleobotanical data. Geologija 27, 891-894.

Rees, P.M., Ziegler, A.M., Gibbs, M.T., Kutzbach, J.E., Behling, P.J., Rowley, D.B., 2002. Permian phytogeographic patterns and climate data/model comparisons. J. Geology 110, $1-31$.

Renault, B., 1893. Bassin houiller et Permien d'Autun et d'Epinac. Études des gîtes minéraux de la France. Fascicule IV, Flore Fossile, 2. Partie. Paris, Atlas, 89 planches.

Renault, B., 1896. Bassin houiller et Permien d'Autun et d'Epinac. Études des gîtes minéraux de la France. Fascicule IV, Flore Fossile, 2. Partie. Paris, Texte (578 pp.).

Ricardi-Branco, F., 2008. Venezuelan paleoflora of the Pennsylvanian-Early Permian: paleobiogeographical relationships to central and western equatorial pangea. Gondwana Res. 14, 297-305.

Rohn, R., Rösler, O., 1987. Relações entre a flora permiana do Gondvana e as floras das províncias setentrionais. 2. X Congresso Brasileiro de Paleontologia. Sociedade Brasileira de Paleontologia, Rio de Janeiro, pp. 885-899.

Roscher, R.M., Schneider, J.W., 2006. Permo-Carboniferous climate: Early Pennsylvanian to Late Permian climate of central Europe in a regional and global context. In: Lucas, S.G., Cassins, G., Schneider, J.W. (Eds.), Non-marine Permian Biostratigraphy And Biochronology. The Geol. Soc. Spec. Publ. 265, London, pp. 95-136.

Rösler, O., 1978. The Brazilian Eogondwanic floral succession. Boletim IG-USP 9, 85-90.

Ross, C.A., Ross, J.R.P., 1985. Carboniferous and early Permian biogeography. Geologija 13 27-30.

Rößler, R., 2006. Two remarkable Permian petrified forests: correlation, comparison and significance. In: Lucas, S.G., Cassinis, G., Schneider, J.W. (Eds.), Non-marine Permian Biostratigraphy and Biochronology. The Geological Society of London Spec. Publ. 265, London, pp. 39-63.

Rößler, R., 2014. Die Bewurzelung permischer Calamiten - Aussage eines Schlüsselfundes zur Existenz freistehender baumförmiger Schachtelhalmgewäche innerhalb de Paläofloren des äquatornahen Gondwana. Freiberger Forschungshefte C 548 Paläontologie, Stratigraphie, Fazies 22, 9-37.

Rößler, R. Galtier, J., 2002a. First Grammatopteris tree ferns from the Southern Hemisphere - new insights in the evolution of the Osmundaceae from the Permian of Brazil. Rev. Palaeobot. Palynol. 121, 205-230.

Rößler, R., Galtier, J., 2002b. Dernbachia brasiliensis gen. nov. et sp. nov. - a new small tree fern from the Permian of NE Brazil. Rev. Palaeobot. Palynol. 122, 239-263.

Rößler, R., Galtier, J., 2003. The first evidence of the fern Botryopteris from the Permian o the Southern Hemisphere reflecting growth form diversity. Rev. Palaeobot. Palynol. 127, 99-124.

Rößler, R., Noll, R., 2002. Der permische versteinerte Wald von Araguaina/BrasilienGeologie, Taphonomie und Fossilführung. Veröffentlichungen des Naturhistorischen Museums Schleusingen 25, 5-44.

Rößler, R., Noll, R., 2006. Sphenopsids of the Permian (I): the largest known anatomically preserved calamite, an exceptional find from the petrified forest of Chemnitz, Germany. Rev. Palaeobot. Palynol. 140, 145-162.

Rößler, R., Noll, R., 2007. Calamitea Cotta, the correct name for calamitean sphenopsids currently classified as Calamodendron Brongniart. Rev. Palaeobot. Palynol. 144, 157-180.

Rößler, R., Noll, R., 2010. Anatomy and branching of Arthopitys bistriata (Cotta) - new observations from the Permian Petrified Forest of Chemnitz, Germany. Int. J. Coal Geol. 83, 103-124.

Rößler, R., Feng, Z., Noll, R., 2012. The largest calamite and its growth architecture Arthropitys bistriata from the early Permian Petrified Forest of Chemnitz. Rev. Palaeobot. Palynol. 185, 64-78.

Rößler, R., Merbitz, M., Annacker, V., Noll, R., Neregato, R., Rohn, R., 2014. The root systems of Permian arborescent sphenopsids: evidence from both the northern and southern hemispheres. Palaeontogr. Abt. B 290, 65-107.

Santos, R.V., Souza, P.A., Alvarenga, C.J.S., Dantas, E.L., Pimentel, M.M., Oliveira, C.G., Araújo, L.M., 2006. Shrimp U-Pb zircon dating and palynology of bentonitic layers from the Permian Irati Formation, Paraná Basin, Brazil. Gondwana Res. 9, 456-463.

Scotese, C.S., 1999. Paleomap Project. Available at: http://www.scotese.com (Accessed in 10/11/2009).

Scotese, C.R., Barret, S.F., 1990. Gondwana's movement over the South Pole during the Palaeozoic: evidence from lithological indicators of climate. In: McKerrow, W.S. Scotese, C.R. (Eds.), Palaeozoic Palaeogeography and Biogeography. Geol. Soc. Memoir 12, London, pp. 94-123.

Scotese, C.R., Langford, R.P., 1995. Pangea and the paleogeography of the Permian. In: Scholle, P.A., Peryt, T.M., Ulmer-Scholle, D.S. (Eds.), The Permian of the Northern Pangea. Springer Verlag, Berlin, pp. 3-19.

Solms-Laubach, H., 1913. Tietea singularis, ein neuer fossiler Pteridineen-Stamm aus Brasilien. Zeitschr. Botanik 5, 673-700.

Tabor, N.J., Poulsen, C.J., 2008. Palaeoclimate across the Late Pennsylvanian-Early Permian tropical palaeolatitudes: a review of climate indicators, their distribution, and relation to palaeophysiographic climate factors. Palaeogeogr. Palaeoclimatol. Palaeoecol. 268, 293-310. 
Tavares, T.M.V., 2011. Estudo de Marattiales da "Floresta Petrificada do Tocantins Setentrional" (Permiano, Bacia do Parnaíba). (Ph.D. Thesis). Instituto de Geociências e Ciências Exatas - Universidade Estadual Paulista "Júlio de Mesquita Filho", Rio Claro (184 pp).

Tavares, T.M.V., Rohn, R., Rößler, R., Feng, Z., Noll, R., 2014. Petrified Marattiales pinnae from the Lower Permian of North-Western Gondwana (Parnaíba Basin, Brazil). Rev. Palaeobot. Palynol. 201, 12-28.

Thomas, B.A., 2013. In situ stems: preservation states and growth habits of the Pennsylvanian (Carboniferous) calamitaleans based upon new studies of Calamites Sternberg 1820 in the Duckmantian at Brymbo, North Wales, UK. Palaeontology 57, 21-36.

Wang, S.J., Li, S.S., Hilton, J., Galtier, J., 2003. A new species of sphenopsid stem Arthropitys from Late Permian volcaniclastic sediments of China. Rev. Palaeobot. Palynol. 126, 65-81.

Wang, S.J., Hilton, J., Galtier, J., Tian, B., 2006. A large anatomically preserved calamitean stem from the Upper Permian of southwest China and its implications for calamitean development and functional anatomy. Plant Syst. Evol. 261, 229-244.
Wnuk, C., 1996. The development of floristic provinciality during the Middle and Late Paleozoic. Rev. Palaeobot. Palynol. 90, 5-40.

Ziegler, A.M., Hulver, M.L., Rowley, D.B., 1997. Permian world topography and climate. In: Martini, IP. (Ed.), Late Glacial and Postglacial Environments Changes: Quaternary, Carboniferous-Permian and Proterozoic. Oxford University Press, Oxford, pp. 111-146.

\section{Further Reading}

Caldas, E.B., Mussa, D., Lima-Filho, F.P., Rösler, O., 1989. Nota sobre a ocorrência de uma floresta petrificada de idade permiana em Teresina, Piauí. Boletim IG-USP, Publicação Especial 7, 69-87. 